\title{
Antibacterial Action of Nanoparticle Loaded Nanocomposites Based on Graphene and Its Derivatives: A Mini-Review
}

\author{
Ana María Díez-Pascual *(iD) \\ Department of Analytical Chemistry, Physical Chemistry and Chemical Engineering, Faculty of Sciences, \\ Institute of Chemistry Research “Andrés M. del Río" (IQAR), University of Alcalá, Ctra. Madrid-Barcelona, \\ Km. 33.6, 28871 Alcalá de Henares, Madrid, Spain
}

Received: 29 March 2020; Accepted: 13 May 2020; Published: 18 May 2020

\begin{abstract}
Bacterial infections constitute a severe problem in various areas of everyday life, causing pain and death, and adding enormous costs to healthcare worldwide. Besides, they cause important concerns in other industries, such as cloth, food packaging, and biomedicine, among others. Despite the intensive efforts of academics and researchers, there is lack of a general solutions to restrict bacterial growth. Among the various approaches, the use of antibacterial nanomaterials is a very promising way to fight the microorganisms due to their high specific surface area and intrinsic or chemically incorporated antibacterial action. Graphene, a 2D carbon-based ultra-thin biocompatible nanomaterial with excellent mechanical, thermal, and electrical properties, and its derivatives, graphene oxide $(\mathrm{GO})$ and reduced graphene oxide $(\mathrm{rGO})$, are highly suitable candidates for restricting microbial infections. However, the mechanisms of antimicrobial action, their cytotoxicity, and other issues remain unclear. This mini-review provides select examples on the leading advances in the development of antimicrobial nanocomposites incorporating inorganic nanoparticles and graphene or its derivatives, with the aim of providing a better understanding of the antibacterial properties of graphene-based nanomaterials.
\end{abstract}

Keywords: antibacterial activity; nanocomposites; bacterial infection; antibiotic resistance; graphene; graphene oxide; reduced graphene oxide

\section{Introduction}

Bacterial growth is an increasing issue in everyday life, highly responsible for noteworthy harm in several industries, including cloth, water treatment, biomedicine, and food packaging [1]. Concerns related to the appearance of microorganisms that have become resistant to antibiotics have recently encouraged the search for new treatments of infectious diseases. For instance, some Gram-positive (e.g., Staphylococcus aureus) and Gram-negative (Escherichia coli, Pseudomonas aeruginosa) bacteria have turned into multi-drug resistant (MDR) pathogens and are one of the leading causes of hospital-acquired infections. Therefore, new, cheap and effective antimicrobial agents for controlling bacterial activity are urgently needed, and nanomaterials constitute a very promising approach.

Many nanomaterials present antimicrobial properties that are not found in their micro/macro-counterparts, like occurs with silver nanoparticles (Ag NPs), which are currently present in wound dressings, coatings for medical devices, and even in food packages. However, commercial applications of Ag NPs are frequently hindered by their agglomeration and consequent loss of antibacterial activity [2].

Carbon can be found in the form of different allotropes, with different shapes and properties. Amongst them, graphene $(G)$, a single monolayer of graphite, and its derivatives graphene oxide 
(GO) and reduced graphene oxide (rGO) are important candidates to be used as antibacterial agents. $\mathrm{G}$ consists of a flat, atomically thick single layer of $\mathrm{sp}^{2}$ carbon atoms forming a honeycomb structure (Figure 1). It displays exceptional thermal, mechanical, and electronic properties [3]; very high electron mobility $\left(15,000 \mathrm{~cm}^{2} / \mathrm{V} \times \mathrm{s}\right)$ and very large surface area $\left(2630 \mathrm{~m}^{2} / \mathrm{g}\right)$ [4]; an in-plane thermal conductivity close to $5000 \mathrm{~W} / \mathrm{m} \times \mathrm{K}$ [3]; and electrical conductivity of $9.6 \times 10^{7} \mathrm{~S} / \mathrm{m}$. Moreover, $\mathrm{G}$ is one of the strongest materials ever known, with Young modulus of around $1 \mathrm{TPa}$ [5], ultimate strength of $130 \mathrm{GPa}$, and breaking strength of $\sim 42 \mathrm{~N} / \mathrm{m}$ [6]. Further, the absorption of $\mathrm{G}$ sheet is nearly constant and equal to $2.3 \%$. However, it is hydrophobic, cannot be dispersed in polar solvents, has poor solubility, and is difficult to be processed in solution, which has hindered its applications.

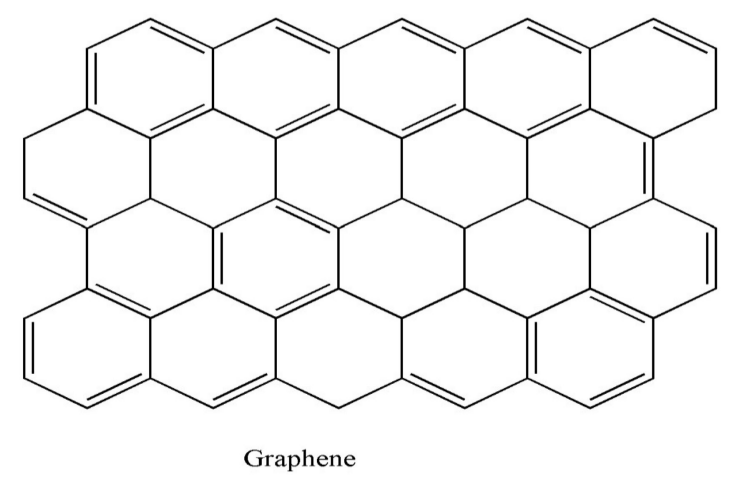

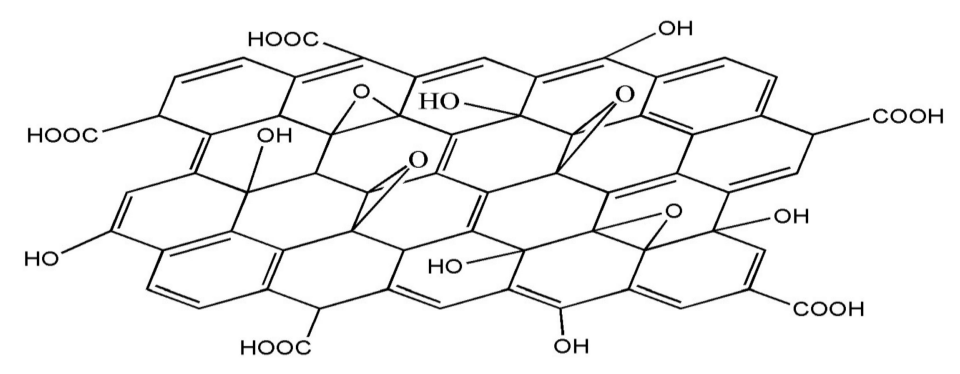

Graphene Oxide

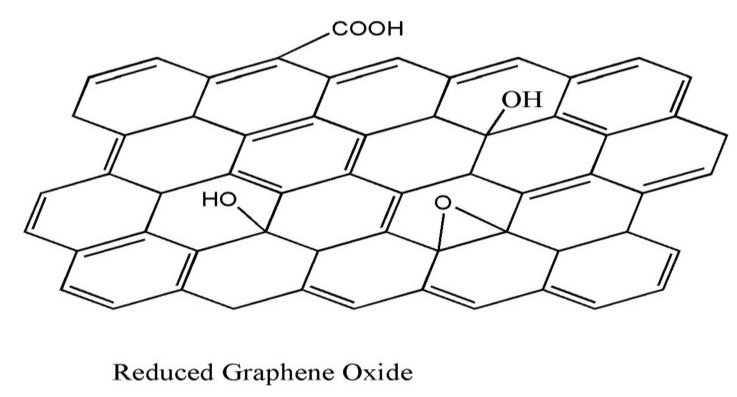

Figure 1. Schematic illustration of the chemical structure of graphene $(G)$ and its derivatives, graphene oxide (GO) and reduced graphene oxide (rGO).

$\mathrm{G}$ can be manufactured by numerous techniques, including exfoliation, epitaxial growth, chemical vapor deposition (CVD), and chemical and electrochemical methods [7]. Mechanical exfoliation was the first method established to separate monolayer $G$ by peeling it off from graphite flakes using a Scotch tape. This process yields $\mathrm{G}$ sheets of high quality although it is not appropriate for mass production.

Epitaxial growth is a substrate-based technique in which $\mathrm{G}$ is grown on a $\mathrm{SiC}$ single-crystal by thermal treatment under vacuum at high temperature $\left(\sim 130{ }^{\circ} \mathrm{C}\right)$. The thickness of $\mathrm{G}$ layers can be 
tailored by controlling temperature and time, and the uniformity of the thickness improves with an annealing process [8].

Chemical vapour deposition (CVD) processes are the most suitable, simplest, and cost-effective to manufacture $G$ on a large scale. $G$ is straightforwardly grown on a substrate made of a transition metal $(\mathrm{Cu}, \mathrm{Ni}, \mathrm{Pt}, \mathrm{Pd}, \mathrm{Ru}, \mathrm{Ir})$ via saturation of carbon upon exposure to a hydrocarbon gas (i.e., methane) at a high temperature [4]. As the substrate cools, the solubility of carbon on the substrate decreases and the carbon precipitates to form mono- to multilayer $\mathrm{G}$ sheets. The main drawbacks are the challenging control of the film thickness and the requirement of expensive substrates.

Chemical solution processes are low-cost large-scale production methods to synthesize G [8]. The main limitation of these methods is the insolubility of G. Nonetheless, the reaction with strong oxidizing agents, such as $\mathrm{H}_{2} \mathrm{SO}_{4}, \mathrm{HNO}_{3}$, or $\mathrm{KMnO}_{4}$, results in the anchoring of oxygen functional groups to both the basal plane and the edges of $G$ sheets, leading to GO (Figure 1), which is soluble in numerous solvents, such as water, dimethylformamide (DMF), tetrahydrofurane (THF), and chloroform [9]. Due to its dispersibility in common organic solvents, GO is highly suitable as a filler in polymeric nanocomposites.

Another approach, scarcely used, is electrochemical exfoliation, based on the penetration of graphite by ions from the solution forced by the applied potential. $G$ obtained by this method can be dispersed in organic solvents such as DMF, which enables the fabrication of thin films [8]. After reduction via treatment with $\mathrm{HNO}_{3}$ or under vacuum, layers with good transport and optical properties can be obtained.

GO is an oxidized form of $G$ that contains epoxides, hydroxyls, and carbonyls on the basal planes and carboxyls on the edges (Figure 1). Accordingly, some properties of GO differ from those of G [9]: The $\mathrm{sp}^{3}$ carbon atoms in GO increase the interlayer spacing, improving its ability to retain compounds. The attached groups and lattice defects modify the electronic structure of $G$ and serve as strong scattering centers that affect the electrical transport. Thus, it presents significantly lower electron mobility (ca. $0.1 \mathrm{~cm}^{2} / \mathrm{V} \mathrm{s}$ ), and it is typically insulating, with a sheet resistance of about $10^{12} \Omega / \mathrm{sq}$ or higher [10]. It has a low thermal conductivity of about $1 \mathrm{~W} / \mathrm{mK}$, and its mechanical properties depend on the number of defects and thermal treatment, with a Young modulus ranging from $200 \mathrm{GPa}$ to $1 \mathrm{TPa}$ [11]. Moreover, it shows aqueous processability, amphiphilicity, surface functionalization capability, and versatility. More importantly, it is highly hydrophilic and can form stable aqueous colloids to facilitate the assembly of macroscopic structures [12], which is crucial for large-scale uses.

GO can be manufactured by "bottom-up" and "top-down" methods. The first ones, in which simple carbon molecules are used, like those described above for pristine $G$, are time-consuming and face problems of scalability. Thus, top-down strategies are widely employed, including four main approaches [10]: Staudenmaier, Hofmann, Brodie, and Hummers. The most employed, the Hummers' method, consists of the addition of $\mathrm{KMnO}_{4}$ to a solution of graphite, $\mathrm{NaNO}_{3}$, and $\mathrm{H}_{2} \mathrm{SO}_{4}$. Many variations of this method have been reported, with improvements constantly being explored to achieve better results and cheaper processes. For instance, approaches without using $\mathrm{NaNO}_{3}$ eliminate the evolution of $\mathrm{NO}_{2} / \mathrm{N}_{2} \mathrm{O}_{4}$ toxic gasses and simplify the disposal of waste water because of the inexistence of $\mathrm{Na}^{+}$and $\mathrm{NO}_{3}{ }^{-}$ions [13].

GO can also be synthesized from graphite oxide by using sonication, stirring, or a combination of both. Sonication is a time-effective way of fully exfoliating graphite oxide, although it can seriously harm the graphene flakes, reducing their size from microns to nanometres, and even producing graphene platelets. Mechanical stirring is a less heavy-handed approach, albeit it involves longer periods of time.

GO can be partly reduced to graphene-like sheets by eliminating oxygen-containing groups with the recovery of a conjugated structure (Figure 1). The rGO sheets are considered as functionalized G or chemically modified G [10]. The aim is to attain graphene-like materials comparable to the pristine $\mathrm{G}$ obtained from direct mechanical exfoliation of graphite both in structure and properties. However, residual functional groups and defects considerably modify the structure of the carbon 
plane; therefore, the properties of rGO differ from those of G. In particular, the electrical conductivity of rGO is typically in the range of $10-23 \mathrm{~S} / \mathrm{cm}$, and its thermal conductivity is about $60 \mathrm{~W} / \mathrm{m} \times \mathrm{K}$ [14], much lower than that of pristine G.

The rGO synthesis can be performed by chemical, thermal, or photochemical methods. The thermal annealing consists of the reduction of GO by means of rapid heating ( $>2000 \mathrm{C} / \mathrm{min})$ [15]. The exfoliation is caused by the evolution of $\mathrm{CO}$ or $\mathrm{CO}_{2}$ gases within the spaces between graphene sheets during the heating. This method cannot be used for GO films on substrates with a low melting-point, such as glass and polymers. Thermal annealing can also be accomplished by microwave irradiation or via photo-reduction [16], using the energy emitted by a flash lamp or a laser. This procedure can result in higher level of GO reduction, as the lamp/laser can offer higher energy than thermal annealing, leading to rGO films with higher conductivity [17].

Reduction by chemical reagents relies on their chemical reactions with GO, and can be performed at room temperature or on applying moderate heating. The reagent more typically used is hydrazine monohydrate [18]. However, this is a toxic and explosive chemical; hence, other "green" reducing agents have been proposed like ascorbic acid [19], sodium citrate [20], dopamine [21], sugar, aminoacids, etc. Electrochemical reduction is also possible, and does not require chemical reagents. The reduction is exclusively driven by the electron exchange between GO and the electrodes in a conventional electrochemical cell [22].

Regarding the biocompatibility of graphene-based materials, that is, their ability to interact with the living body, tissues, and cells without harmful effects, controversial results have been reported [23]. Their interactions with living cells depend on a large number of factors, including their hydrophilicity, purity, level of functionalization, lateral size, layer number, and so forth $[24,25]$. Thus, they can damage cell membranes, comprising phospholipids and cholesterol, resulting in potential cytotoxic effects. Pristine graphene cannot bind the phospholipids via electrostatic interactions, while can interact with their fatty acid chains by means of hydrophobic interactions [24]. In contrast, GO can electrostatically interact with the phospholipids since it possesses oxygenated functional groups on its surface. Besides, these nanoscale carbon materials can penetrate the cytoplasm, causing the leakage of cytoplasmic content, mitochondrial disorders, and lipid peroxidation. Moreover, if they enter the nucleus, they can subsequently react with DNA and induce genotoxic effects [26]. Most studies state that rGO is less toxic than GO [26], due to the reduction of functional groups. However, a few investigations have shown that rGO is more harmful to some cells like glioma ones [27]. Cytotoxicity can be minimized by attachment onto GO or rGO surfaces of biocompatible polymers incorporating amine and quaternary ammonium groups like chitosan (CS) [28], polyethyleneimine (PEI) [29], or poly(L-lysine) (PLL) [30]. Although the potential of GO for biomedical purposes has been clearly demonstrated, the lack of live cell compatibility information has limited its practical applications.

\section{Antibacterial Action of Graphene and Its Derivatives}

The defects contained in GO and rGO sheets strongly influence not only their physical properties but also their chemical and biochemical. Hence, the nanomaterial-bacteria interactions are conditioned by the type of graphene-based nanomaterial. Further, depending on the synthesis process, the number of oxygenated groups including hydroxyl, ketone, epoxy, ether, and carboxylic acid will vary, resulting in C/O ratios ranging from 0.43 [22] to 25.3 [31]. The degree of hydrophilicity plays a crucial role in antibacterial activity. $\mathrm{G}$ and $\mathrm{rGO}$ are hydrophobic, and their nanosheets tend to aggregate by means of $\pi-\pi$ stacking interactions, favoring a strong and rapid adsorption of the bacteria on their surfaces. In contrast, GO is hydrophilic and amphiphilic, and bacterial adhesion has been reported to be slower, following a reversible model [32]. Besides, other parameters such as the nanomaterial surface charge, sheet size, and shape also condition the antibacterial activity. In this regard, G presents a neutral surface charge, while GO and rGO display negatively charged surfaces due to the deprotonation of the hydroxyl and carboxylic acid groups, and this influences bacterial adhesion. In addition, the sheet size can vary from a few nanometers to several micrometers, and the antimicrobial activity has been found 
to decrease as the size increases (ca. 4-fold increase in the antimicrobial activity when GO sheet area decreased from 0.65 to $0.01 \mu \mathrm{m}^{2}$ [33]). It has also been demonstrated that insertion of $\mathrm{G}$ nanosheets within the lipid bilayer is size-dependent [34], and that microscale-sized graphenes tend to adopt a near-perpendicular configuration with respect to the cell wall, whereas nanosheets prefer a parallel position to the lipid bilayer. This is motivated by the preferential attraction between the hydrocarbon tails of the lipids and the lipophilic and flat $\mathrm{G}$ surface that allows the nanomaterial to sink in amongst the lipid tails, embedding the $G$ nanosheets in the cell membrane. Further, it has been shown that the smaller the $\mathrm{G}$ layers are, the more freely they can diffuse into the lipid membrane in a preferential perpendicular orientation, whereas larger sheets prefer to organize themselves across the membrane, embedding themselves in the more lipophilic section of the cell membrane [35]. In addition, other G features like surface topography and roughness can also condition the antibacterial activity [36].

Over the last decade, many works have focused on the antibacterial activity of GO and rGO dispersions [37-44]. The pioneer study by Liu and coworkers [37] provided information on the antibacterial activity of graphitic-based materials against $E$. coli, highlighting that GO displayed the highest action, followed by rGO, graphite, and graphite oxide. In most of the studies, as expected, the antibacterial action increased with increasing time and concentration (Figure 2), the bactericide effect being stronger against Gram-positive bacteria.
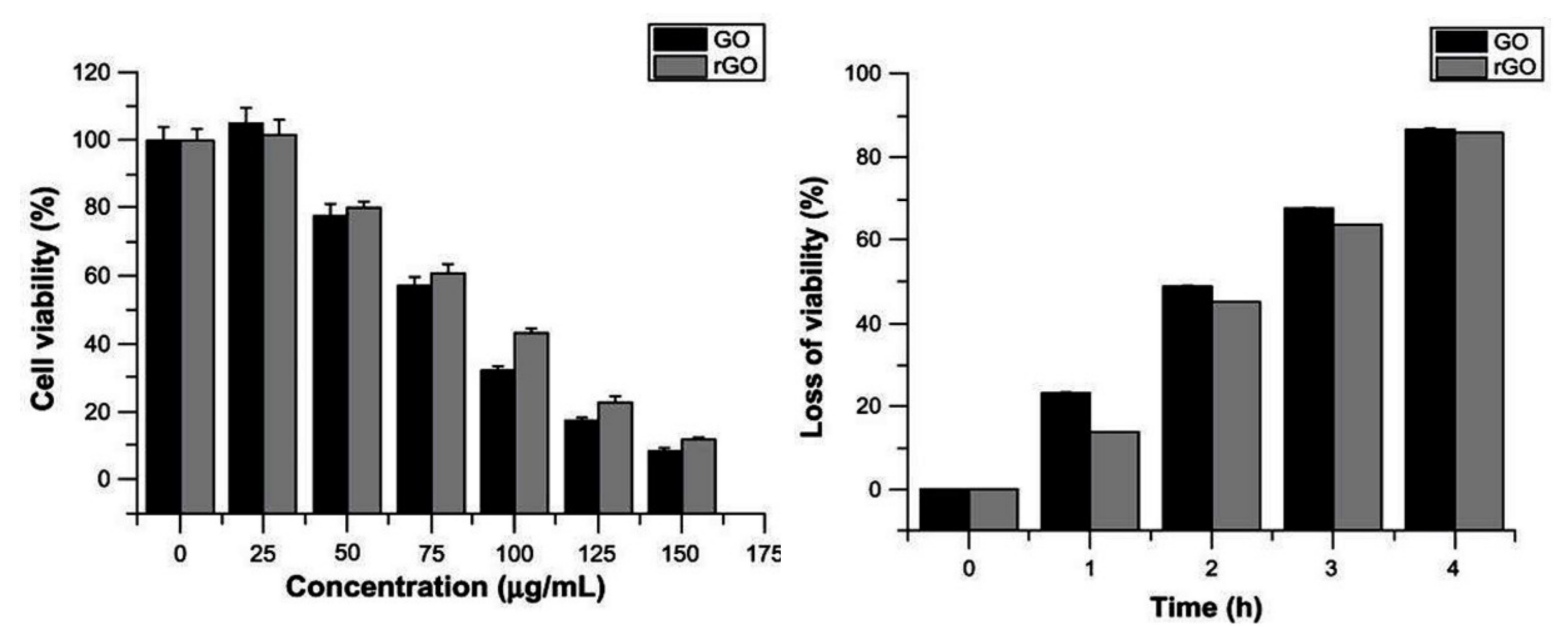

Figure 2. Antibacterial action of graphene oxide (GO) and reduced graphene oxide (rGO) in Pseudomonas aeruginosa. Reproduced from Ref. [44], with permission from Dove Medical Press, 2012.

The lateral dimensions and level of nanomaterial aggregation also play a key role in the antibacterial activity of graphene-based materials. Well-dispersed sheets display stronger activity, since they can cover the cells more easily. Thus, it was found that bacteria can be wrapped by a thin layer of GO, which inhibits cell proliferation, resulting in significant cell viability loss [40]. In contrast, bacteria cells are typically embedded within large rGO aggregates that lead to lower efficacy. Conversely, conductive rGO and G show higher oxidative potential than insulating GO, which would result in a higher bactericide action [38].

Different mechanisms have been reported to explain the antibacterial activity of graphenic materials, namely chemicals such as production of reactive oxygen species (ROS), oxidative stress at the bacterial membrane or extraction of a large amount of phospholipids from the cell membrane, as well as physically induced by the interaction of the sharp edges of graphene with bacterial membranes (resulting in a loss of cell membrane integrity), photo-thermal ablation, and mechanical wrapping, causing cell lysis [12,41,44]. The action could comprise of three stages (Figure 3): (i) cell deposition onto the graphene material, (ii) membrane stress induced by direct contact with sharp nanosheets, and (iii) superoxide anion-independent oxidation. 

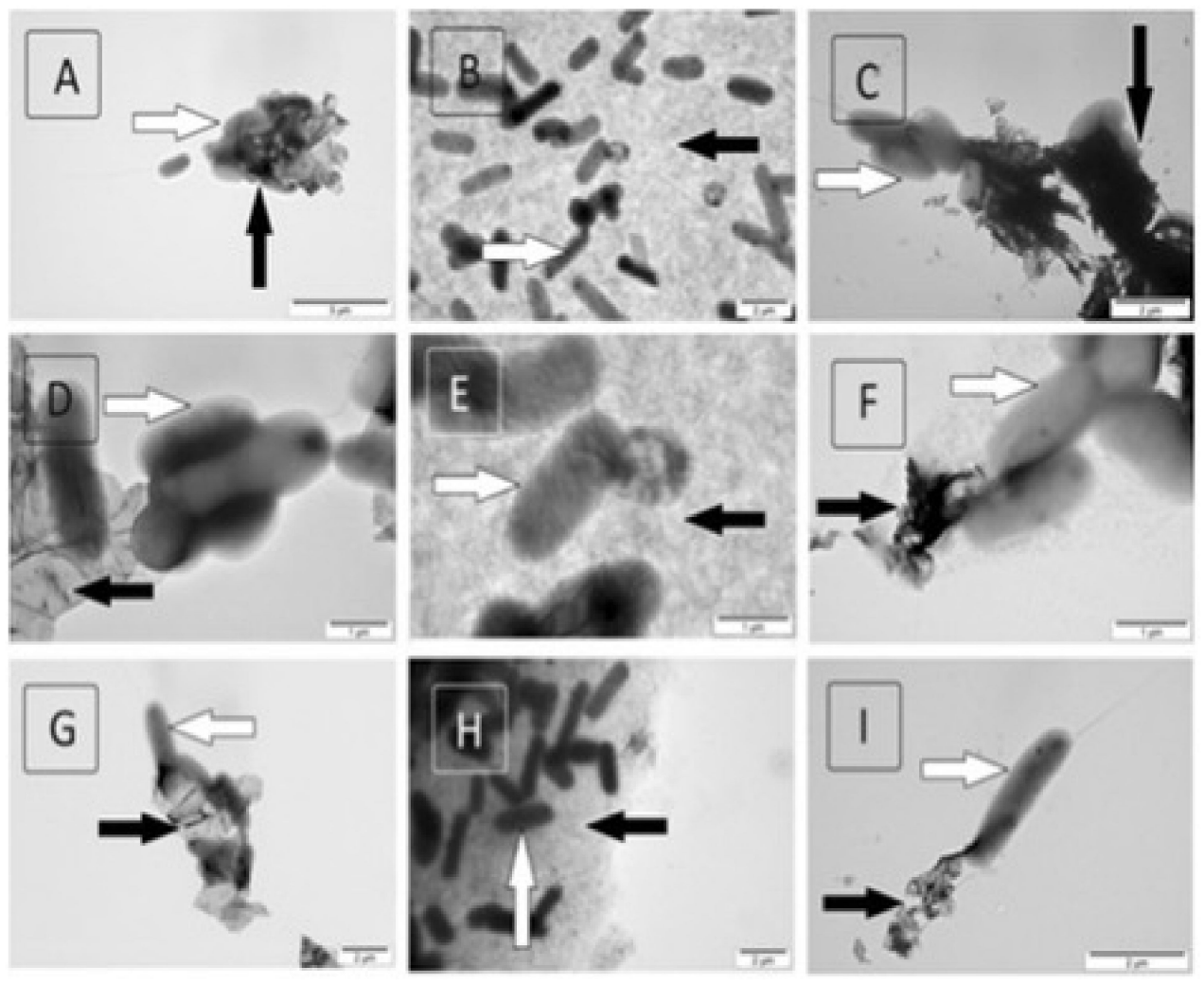

Figure 3. TEM images showing the interaction of graphene-based materials with Salmonella enterica. Pristine graphene (A, D, G), graphene oxide (B, E, H), and reduced graphene oxide (C, F, I). Reproduced from Ref. [41], with permission from SpringerOpen, 2015.

The lipid extraction mechanism has been confirmed by TEM by simulating the interaction between GO and both the outer and inner bacterial membranes (Figure 3). The strong van der Waals interactions between the GO nanosheets and the membrane lipids cause their extraction. Once extracted, hydrophobic interaction plays a leading role wherein the lipid hydrophobic tails spread out mainly on the unoxidized hydrophobic regions of GO, whereas the hydrophilic head groups prefer to contact polar oxide functions via electrostatic interactions. Therefore, both the GO insertion and lipid extraction induced severe membrane stress and reduced cell viability, a process that has been found to be concentration-dependent and increases with increasing GO lateral size.

The interaction of the edges of $G$ nanosheets with bacterial membranes is frequently called the "insertion mode of action". The G sharp edges can act as knives to cut through the bacteria's cell membranes, leading to the leakage of intracellular substrates, thereby causing cell death [38]. Both GO and rGO also display bactericidal behavior towards Gram-negative and Gram-positive bacteria via this mechanism.

Related to the insertion mode of action is another mechanism that stipulates that the destructive effect of $G$ on the bacterial membrane is induced by "direct contact" with the basal plane of the nanomaterial [42,45]. In this regard, the adhesion behavior of two different $E$. coli strains, UTI89 and LF82, towards gold interfaces coated with CVD graphene has been investigated (Figure 4). As can be observed from the SEM micrographs (Figure 4a), neither morphological changes nor membrane damage of the bacteria took place, indicating that such interfaces do not have antibacterial properties. The antibacterial activity of monolayer graphene on $\mathrm{Cu}, \mathrm{Ge}$, and $\mathrm{SiO}_{2}$ has also been investigated [42], and it was found that films on $\mathrm{Ge}$ and especially on $\mathrm{Cu}$ strongly restricted the proliferation of both $S$. aureus and E. coli. However, graphene films on $\mathrm{SiO}_{2}$ could not inhibit their growth, demonstrating that this nanomaterial has bactericide action on conducting and semiconducting surfaces. Further work [45] demonstrated that the antibacterial efficiency of G-based nanomaterials is not dependent on its sharp 
edges but on the contact that occurs between the nanomaterial basal plane and the bacteria cells. Thus, masking the GO basal plane decreased its antimicrobial efficiency by decreasing the extent of direct contact with the bacteria [46].

(A)

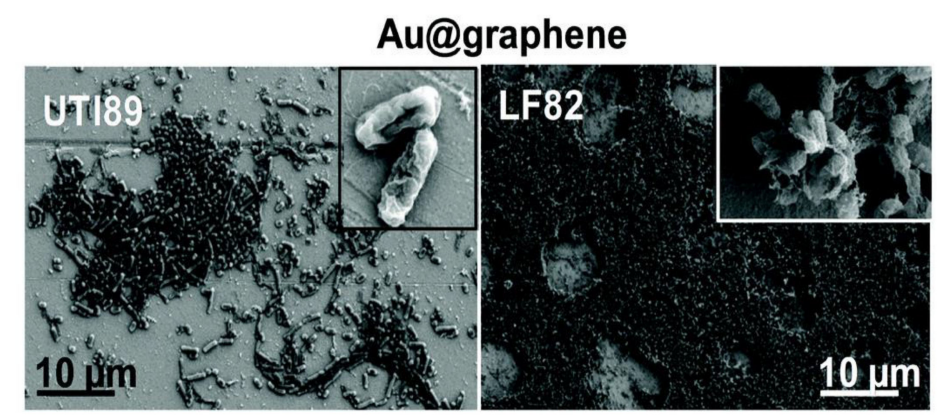

(B)
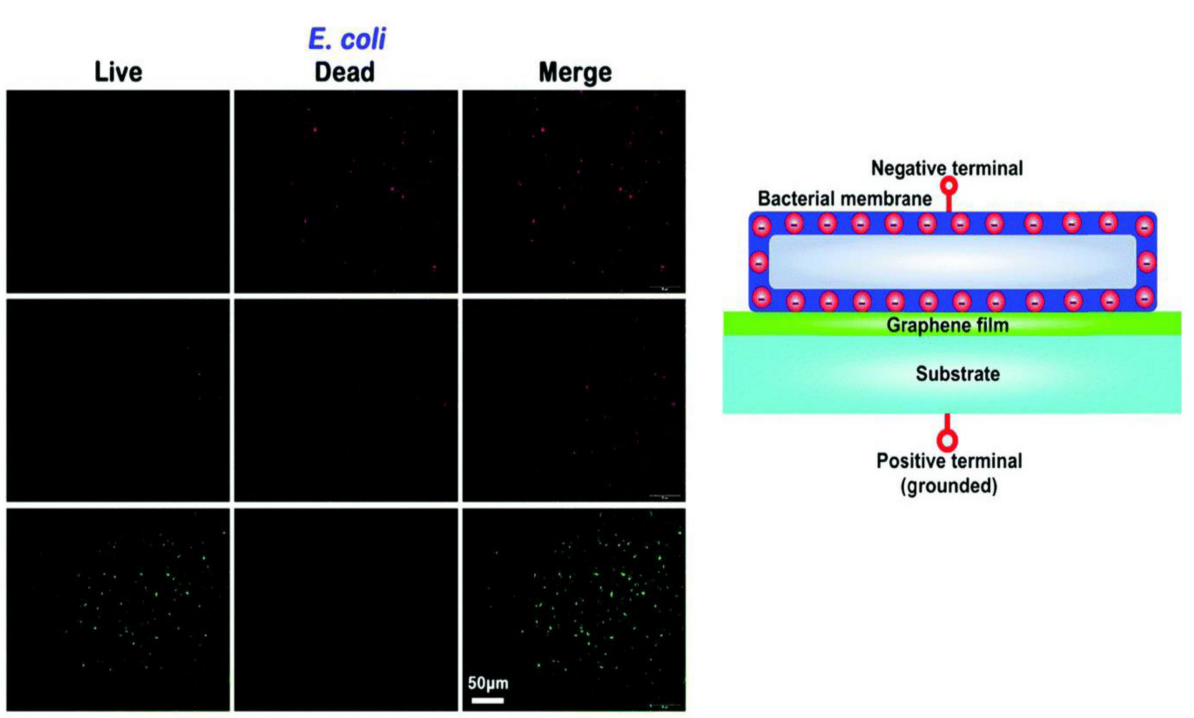

$\mathrm{SiO}_{2} @$ graphene

Figure 4. (A) SEM micrographs of E. coli UTI89 and LF82 on gold coated with CVD graphene; (B) fluorescence images showing the viability of bacteria after $24 \mathrm{~h}$ incubation over different interfaces (live bacteria are green, dead ones are red) and a schematic representation of the proposed mechanism. Reproduced from Ref. [42], with permission from Nature Research Publishing, 2014.

Another potential mechanism of $\mathrm{G}$ antibacterial action could be that its hydrophobic sheets perturbed the protein-protein bonding in the cell membrane, inducing the destabilization of the 3D structure of the protein, hence inducing a self-killing effect [15].

\section{Antibacterial Action of Nanoparticle-Graphene based Nanocomposites}

While graphene-based materials exhibit antibacterial properties, they have a strong tendency to agglomerate, in particular G and rGO, due to strong van der Waals interactions among the sheets, which condition their antibacterial action. This issue can be prevented via formation of nanocomposites by surface modification with metal ions/oxides NPs. Inorganic NPs can enhance graphene properties due to their high surface area-to-volume ratio, which leads to novel chemical, electrical, mechanical, optical, and electro-optical properties that differ from those of their bulk counterparts. Further, the mixing of G and rGO with metal oxide NPs can improve their dispersibility in polar solvents such as water [10]. Thus, numerous nanocomposites have been developed over recent years that combine the bactericide action of inorganic nanoparticles with the inherent antibacterial property of graphene-based nanomaterials to attain synergistic effects, and the most representative examples will be reviewed in the following sections. 


\subsection{Nanocomposites with Silver Nanoparticles}

The antibacterial properties of $\mathrm{Ag}^{+}$and $\mathrm{Ag}$-based composites have been comprehensively explored [47]. $\mathrm{Ag}^{+}$can damage the bacterial membranes and also produce ROS via photocatalytic activation. Nonetheless, when Ag nanoparticles interact with bacteria, they agglomerate; hence their effective specific surface area decreases, leading to reduced antibacterial action [48]. To solve this issue, nanocomposites of graphene and Ag nanoparticles were developed [49,50], although the improvements in antibacterial activity were still limited. Therefore, numerous studies have been reported on GO and rGO nanocomposites comprising Ag nanoparticles [51-62] (Table 1), showing improved performance compared to GO and Ag nanoparticles alone due to synergistic effects; further, the mixture of both constituents considerably reduces the concentrations required to inhibit all bacteria. Thus, significantly higher antibacterial activity was found for AgNPs-GO composites (1:2 ratio), with an average NP size of $80 \mathrm{~nm}$ [52] at a concentration of $200 \mu \mathrm{g} / \mathrm{mL}$ (Table 1), compared to that of GO or AgNPs, attributed to a higher ROS production, hence resulting in stronger oxidative stress and disruption of the cell membrane. Further, the AgNPs attached to GO are more stable and well-dispersed, which also contributes to the higher efficacy. Comparable antibacterial action has been found for similar composites with smaller nanoparticles (ca. $40 \mathrm{~nm}$ ) for an optimal AgNPs:GO ratio of 1:1 even at concentrations as low as $2.5 \mu \mathrm{g} / \mathrm{mL}$ [58].

Bacterial cell disruption seems to be the main mechanism against Gram-negative bacteria, while the inhibition of cell division could account for the lysis of Gram-positive ones. AgNPs-GO nanocomposites cause stronger damage towards E. coli membrane compared to S. aureus, as can be observed in Table 1 . Thus, the antimicrobial potential of these nanocomposites is also influenced by the thickness of the cell wall of the microorganisms. The wall of Gram-positive contains a thick layer $(20-80 \mathrm{~nm})$ of peptidoglycan attached to teichoic acids. In Gram-negative bacteria, the cell wall comprises of a thin $(7-8 \mathrm{~nm})$ peptidoglycan layer and an outer membrane. The thicker peptidoglycan layer in Gram-positive bacteria could account for their higher resistance towards the effects of AgNPs-GO. Their bactericide action can be depicted in four stages (Figure 5) [60]: release of $\mathrm{Ag}^{+}$ions, penetration through the cell membrane, ROS generation, followed by DNA, protein, mitochondrion, lipids and membrane damage, which finally leads to cell death.

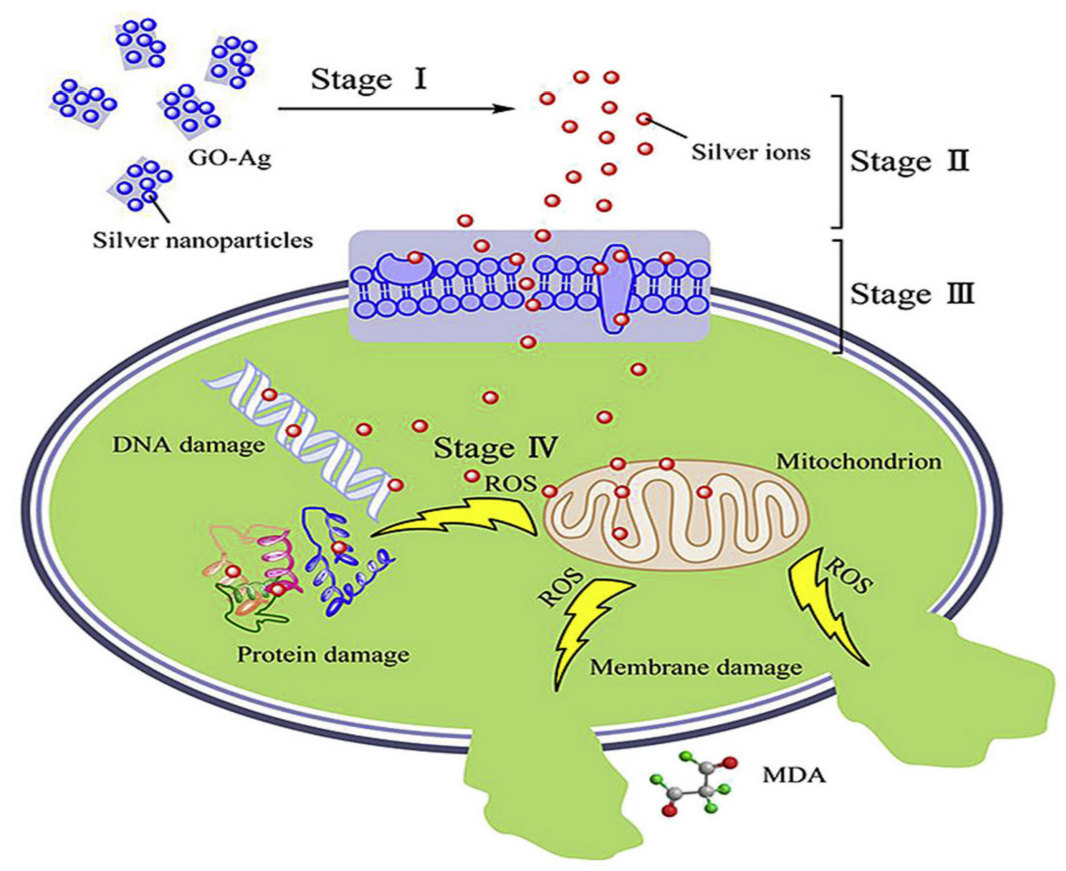

Figure 5. Representation of the antimicrobial action of AgNP-GO nanocomposites. Reproduced from Ref. [60], with permission from Elsevier, 2016. 
Lipids constitute a main target during oxidative stress. Free radicals can directly attack the polyunsaturated fatty acids in the bacteria, yeast their membranes, and activate peroxidation of lipids, resulting in a drop in membrane fluidity, which can significantly disrupt membrane-bound proteins. DNA is also a key target. Mechanisms of DNA damage include abstractions and addition reactions by free radicals, leading to carbon-centered sugar radicals and $\mathrm{OH}$ - or $\mathrm{H}$-adduct radicals of heterocyclic bases. The sugar moieties creating single- and double-strand breaks in the backbone, adducts of base and sugar groups, and cross-links to other molecules can block replication [63].

It is worthy to mention that AgNPs-rGO nanocomposites as antibacterial agents are more limited due to the tendency of the nanosheets to aggregate via strong van der Waals interactions. While the interaction between $\mathrm{G}$ (or $\mathrm{rGO}$ ) and $\mathrm{Ag}^{+}$should be mainly via hydrophobic and van der Waals forces, $\mathrm{Ag}^{+}$nanoparticles have been reported to interact with the negatively charged oxygen-containing functional groups on the GO surface via electrostatic binding [55]. The AgNP-GO nanocomposites showed improved colloidal stability, photo-stability, and antibacterial activities against Gram-negative bacteria compared to AgNPs alone. GO plays a key role in improving the stability of the AgNPs, acting as a platform to prevent their agglomeration. Moreover, composites comprising smaller AgNPs showed better antibacterial activity than those with bigger NPs. This effect of the nanoparticle size has been further corroborated by different authors. Thus, the antibacterial efficacy of AgNP-GO with four NP sizes (10, 30, 50, and $80 \mathrm{~nm}$ ) against E. coli and S. aureus has been tested, and its was found that the composite with the smallest NP showed the best activity [61]. Similarly, a recent study [62] investigated the bactericide action of AgNP-GO (ratio 1:2.3) manufactured via an environmentally friendly one-step approach, which comprised of spherical NPs with different diameters. The smallest NPs (ca. $3.1 \mathrm{~nm}$ ) were obtained for the lowest concentrations of the silver precursor and the lowest synthesis temperatures, and led to an exceptional antibacterial action against Gram-negative E. coli and P. aeruginosa, as well as Gram-positive S. aureus and C. albicans (Table 1). Small-sized AgNPs have a larger surface area, resulting in more efficient cell-particle contact.

\subsection{Nanocomposites with Gold Nanoparticles}

The antibacterial activity of gold NPs also depends on their size and shape. Those of smaller dimensions (ca. less than $2 \mathrm{~nm}$ ) are more likely to penetrate the bacterial cells and cause cell damage, followed by death [64]. Further, triangular-shaped NPs display better activity towards Gram-positive and Gram-negative bacteria than spherical ones [65], since their sharp edges can pierce the membranes of endosomes and translocate to the cytoplasm where they can be retained. The NPs can anchor to the bacterial membrane by electrostatic interaction and disrupt its integrity. They can alter the membrane potential and reduce the ATP levels within the cell, inhibiting the binding of tRNA with ribosomal subunit and thus disturbing translation [66]. Further, Au NPs can produce holes in the cell wall causing leakage of cell contents, and bind with the DNA, hindering transcription. They are also able to generate oxidative via free radical formation: the interaction between small NPs and bacteria probably induces a metabolic imbalance in the bacterial cell, resulting in an increase of ROS production that concluded in bacteria death [64].

Au nanoparticles have also been integrated with GO and rGO [67,68]. These composites also possess higher antibacterial activity than the individual components, and the bacterial cell disruption seems to be induced by the leak of sugars and proteins from the cell membrane when it comes in contact with the nanocomposite [67]. Further, Au nanostructures wrapped by rGO modified with polyethylene glycol (PEG) have been recently applied for the photothermal ablation of bacteria [68], and optimal inhibition of $E$. coli was attained at high temperatures $\left(56-70{ }^{\circ} \mathrm{C}\right)$, Figure 6 . This novel biocompatible process for pathogen ablation opens up a new perspective for treatment of urinary infections. 


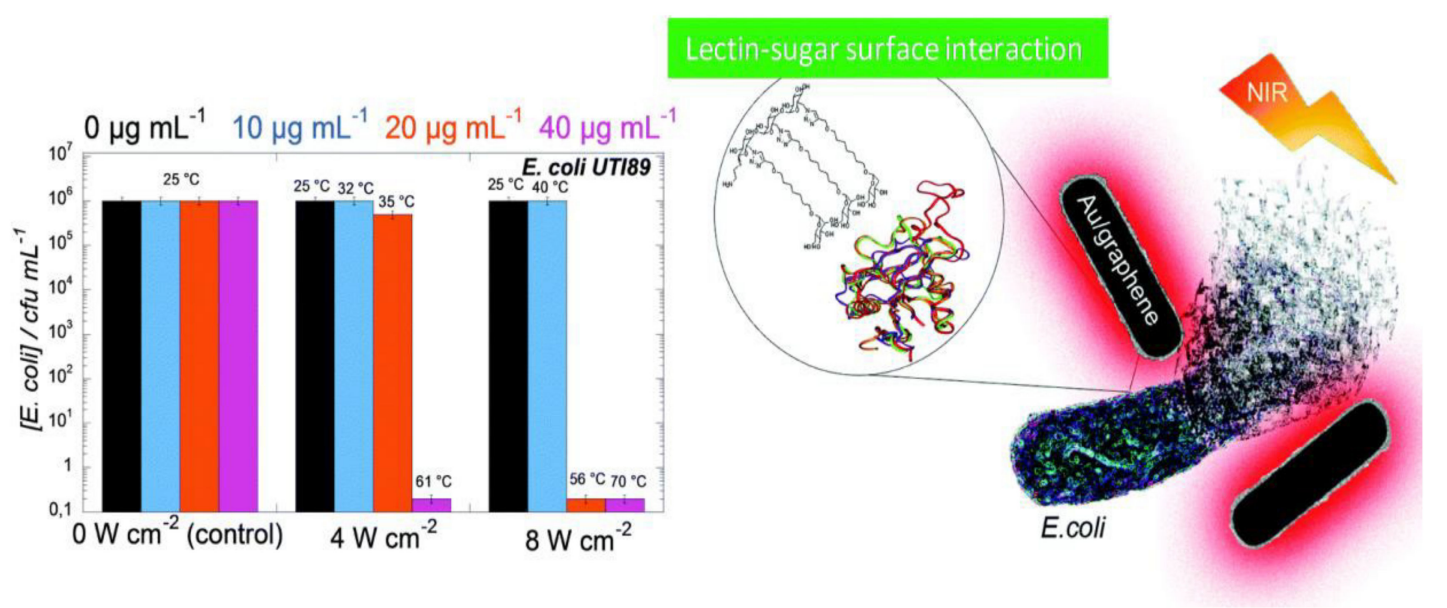

Figure 6. E. coli viability in the presence of rGO-PEG-Au NPs upon irradiation at 4 or $8 \mathrm{~W} \mathrm{~cm}^{-2}$ for 10 min. Reproduced from Ref. [68], with permission from the Royal Society of Chemistry, 2015.

\subsection{Nanocomposites with Cooper Oxide Nanoparticles}

A few studies have also been devoted to investigating the antibacterial action of $\mathrm{Cu}$ [69], $\mathrm{Cu}_{2} \mathrm{O}[70,71]$ or $\mathrm{CuO}$ [72] nanoparticles bound to $\mathrm{GO}$ or rGO. At high concentrations, these nanomaterials are toxic to the majority of microorganisms since the redox properties of $\mathrm{Cu}$ provoke cellular damage including protein and lipid oxidation. Thus, it is crucial to control the release of $\mathrm{Cu}^{2+}$ ions, which produce $\mathrm{ROS}$ species on the bacterial surface. $\mathrm{Cu}_{2} \mathrm{O}$ can interact with $\mathrm{GO}$ and rGO nanosheets via physisorption, electrostatic attraction, or charge-transfer. The nanocomposites have improved bactericidal properties than each individual component, since the graphenic nanosheets can stimulate the $\mathrm{Cu}_{2} \mathrm{O}$ to generate more $\mathrm{ROS}$ [71], and also prevent nanosheet aggregation. Simultaneously, rGO prevents $\mathrm{Cu}_{2} \mathrm{O}$ from reacting with the environment and releasing $\mathrm{Cu}^{2+}$ rapidly.

In a recent study [71], the antibacterial properties of $\mathrm{Cu}_{2} \mathrm{O}$ nanoparticles and a $\mathrm{rGO}-\mathrm{Cu}_{2} \mathrm{O}$ nanocomposite were compared as a function of time (Figure $7 \mathrm{a}, \mathrm{b}$ ). When the samples were stored in phosphate buffered saline (PBS) for less than seven days, the nanocomposite showed about $14 \%$ higher antibacterial activity against $E$. coli and $S$. aureus than the $\mathrm{Cu}_{2} \mathrm{O}$ nanoparticles, which only produced ROS until the third day, while the nanocomposite systematically produced ROS during this period. For longer periods, the activity of the nanocomposite was considerably higher than that of $\mathrm{Cu}_{2} \mathrm{O}$ (i.e., $40 \%$ and $35 \%$ better against $E$. coli and S. Aureus after one month). The antibacterial mechanism seems to be based on ROS generation (Figure 7d). Upon light illumination, the photoinduced electron would be transferred from the $\mathrm{Cu}_{2} \mathrm{O}$ to the $\mathrm{rGO}$, which could suppress the recombination of electron-hole pairs. The rGO could accept the photoexcited electrons from $\mathrm{Cu}_{2} \mathrm{O}$, enabling improved charge transfer between the bacteria and the $\mathrm{rGO}-\mathrm{Cu}_{2} \mathrm{O}$ nanocomposite [70].

Nanocomposites of $\mathrm{CuO}$ nanoparticles and $\mathrm{GO}$ have also been developed [72], which were found to be effective antibacterial nanomaterials, strongly inhibiting the proliferation of both E. coli and S. typhimurium bacteria compared to $\mathrm{GO}$ or $\mathrm{CuO}$ alone. The surface morphology of the nanocomposite significantly differed from that of the pure components (Figure 8), as revealed by scanning electron microscopy (SEM), transmission electron microscopy (TEM), and atomic force microscopy (AFM), and this could account for the improved bactericide action. An inspection of the nanomaterial surface (Figure 8c,e) shows the underlying sheets of GO covered by a high concentration of well-dispersed ellipsoidal NPs, with the short and long axis dimensions being $\sim 80 \mathrm{~nm}$ and $\sim 190 \mathrm{~nm}$, respectively. AFM imaging (Figure 8f,g) revealed that the GO and GO-CuO flakes were about 12 and $13 \mathrm{~nm}$ in thickness, respectively, indicating that the nanocomposite is composed of a few layers of GO covered by a thin $\mathrm{CuO}$ coating. The energy-dispersive $\mathrm{X}$-ray (EDX) mapping confirmed that the material on the modified GO contains cooper and oxygen. 

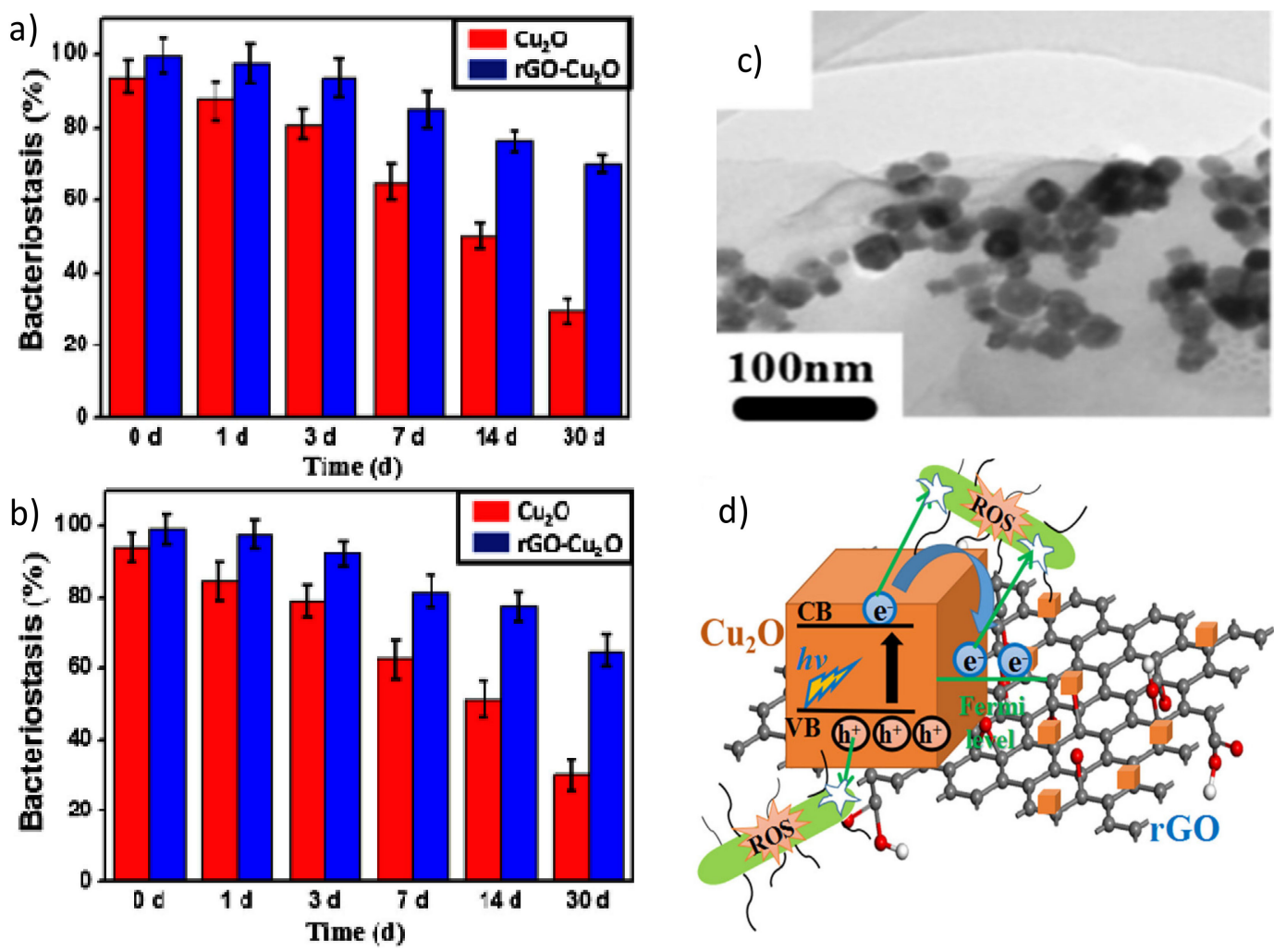

Figure 7. Percentage of bacterial reduction of E. coli (a) and S. aureus (b) in the presence of $\mathrm{Cu}_{2} \mathrm{O}$ nanoparticles and the $\mathrm{Cu}_{2} \mathrm{O}-\mathrm{rGO}$ nanocomposite after immersion in phosphate buffered saline (PBS) for different days. TEM image of the $\mathrm{Cu}_{2} \mathrm{O}-\mathrm{rGO}$ nanocomposite (c). Schematic representation of the mechanism of ROS production of the $\mathrm{Cu}_{2} \mathrm{O}-\mathrm{rGO}$ nanocomposite (d). Reproduced from Ref. [71], with permission from Elsevier, 2019.

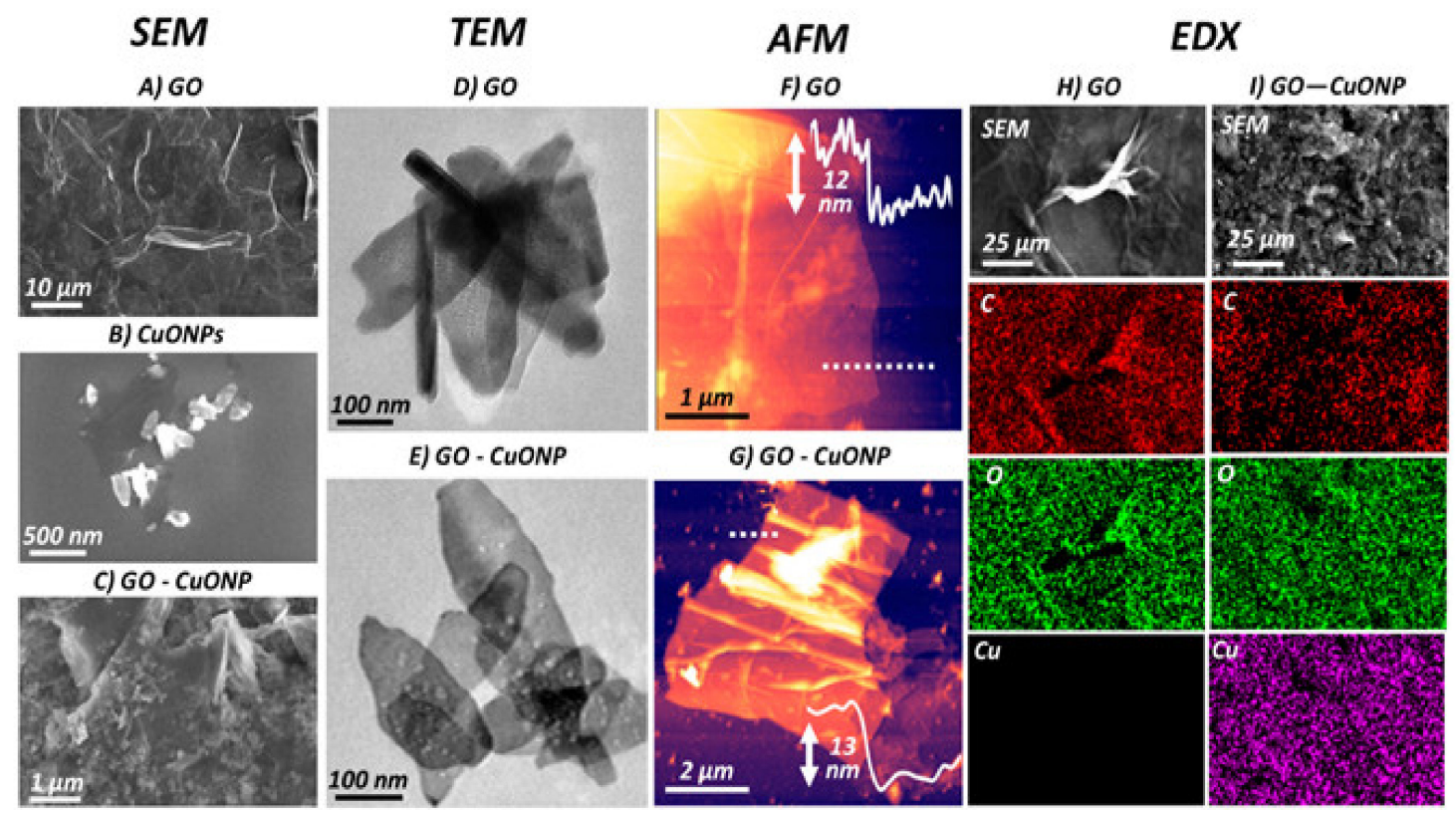

Figure 8. SEM images of (A) GO, (B) CuO nanoparticles, and (C) GO-CuO nanocomposite. (D and E) TEM and (F and G) AFM images of GO and GO-CuO, respectively. Energy-dispersive X-ray (EDX) spectral map for H) GO and I) GO-CuO nanocomposite. Reprinted from Ref. [72], with permission from the American Chemical Society, 2019. 


\subsection{Nanocomposites with Titanium Oxide Nanoparticles}

$\mathrm{TiO}_{2}$ is an important semiconducting material due to its chemical inertness, non-toxicity, low cost, excellent chemical/thermal stability, high UV absorption, and strong antibacterial activity against a large variety of microorganisms [73-75]. A few works have been recently reported on the photocatalytic antibacterial properties of $\mathrm{GO}$ and $\mathrm{rGO}$ nanocomposites incorporating $\mathrm{TiO}_{2}$ [76-79], which provide a green and effective method for the inactivation of various microorganisms by generating ROS. The photocatalytic activity of $\mathrm{TiO}_{2}$ improves after coupling with $\mathrm{G}$ derivatives, attributed to the remarkable electron conductivity of the carbon nanomaterial that provides a 2D network reservoir to accept as well as shuttle photogenerated electrons from the semiconductor, which results in the separation and prolonged lifetime of hole-electron pairs [80]. Further, $\mathrm{GO}$ can interact with $\mathrm{TiO}_{2}$ via $\mathrm{H}$-bonding and polar forces, while in the case of rGO, the hydrophobic interactions play a dominant role. The antibacterial activity of a $\mathrm{GO}-\mathrm{TiO}_{2}$ nanocomposites against E. coli. was investigated, and a complete inactivation was found under light irradiation for $30 \mathrm{~min}$ at a concentration of $180 \mu \mathrm{g} / \mathrm{mL}$ [77], Table 1. The inexpensiveness of $\mathrm{TiO}_{2}$ and the easiness of manufacturing magnetic $\mathrm{GO}-\mathrm{TiO}_{2}$ make them suitable for water disinfection treatment. In addition, cotton fabrics have been covered with rGO decorated with $\mathrm{TiO}_{2}$ nanoparticles in order to provide self-cleaning characteristics and improve the antimicrobial properties [78], and the nanocomposite coating strongly restricted the growth of E. faecalis and $\mathrm{S}$. aureus. In general, studies indicate higher activity of $\mathrm{rGO}-\mathrm{TiO}_{2}$ against Gram-positive bacteria compared to Gram-negative ones. $\mathrm{rGO}^{-\mathrm{TiO}_{2}}$ nanocomposites have also been developed for the synergetic degradation of fluoroquinolone in a pulse discharge plasma (PDP) system [79], and the highest removal efficiency $(99.4 \%$ ) was attained at $5 \mathrm{wt} \%$ rGO content, which was $23.7 \%$ higher than that for $\mathrm{TiO}_{2}$ alone.

\subsection{Nanocomposites with Zinc Oxide Nanoparticles}

$\mathrm{ZnO}$ is another semiconductor photocatalyst widely used as an antibacterial agent $[81,82]$. Its properties depend mainly on its specific surface area and the number of surface sites at which reactions take place with absorbed molecules. The release of $\mathrm{Zn}^{2+}$ has been proposed as one of the principal antibacterial mechanisms of these nanoparticles, together with the penetration and disruption of the bacterial membrane [83]. Nonetheless, as occurs with other nanoparticles, agglomeration hinders efficient antibacterial action. The mixing of GO or rGO with $\mathrm{ZnO}$ nanoparticles can prevent their aggregation, leading to nanocomposites with good environmental stability and better antibacterial properties than each of the components alone [84-91]. ZnO-GO nanoparticles have been prepared via a simple one pot reaction [87] in which the GO aided the $\mathrm{ZnO}$ dispersion, slowed down the $\mathrm{ZnO}$ dissolution and acted as an anchorage point, favoring the direct intimate contact bacteria- $\mathrm{ZnO}$.

The mechanism of photocatalytic inactivation of E. coli by GO-ZnO nanocomposites has also been investigated [88], and it was reported that GO promoted the charge transfer, favoring the bulk production of ROS, hence improving the bacterial inactivation efficiency. ZnO/graphene quantum dot nanocomposites have been synthesized via the hydrothermal method [90] and showed enhanced antibacterial activity on E. coli compared to the individual components, attributed to superior ROS production under UV-irradiation. Further, $\mathrm{ZnO}$ nanoparticles on GO [91] were able to inhibit the growth of E. coli, S. typhimurium, B. subtilis, and E. faecalis bacteria (Figure 9), after $24 \mathrm{~h}$ of incubation. Excellent antibacterial activity of the nanocomposite can be observed with minimum inhibitory concentrations (MIC) of $6.25 \mu \mathrm{g} / \mathrm{mL}$ for E. coli and S. typhimurium, $12.5 \mu \mathrm{g} / \mathrm{mL}$ for B. subtilis, and $25 \mu \mathrm{g} / \mathrm{mL}$ for E. faecalis, significantly lower than those found for the individual components. This proves that GO-ZnO nanocomposites at low concentration can be effectively used to inhibit the growth of bacteria. 

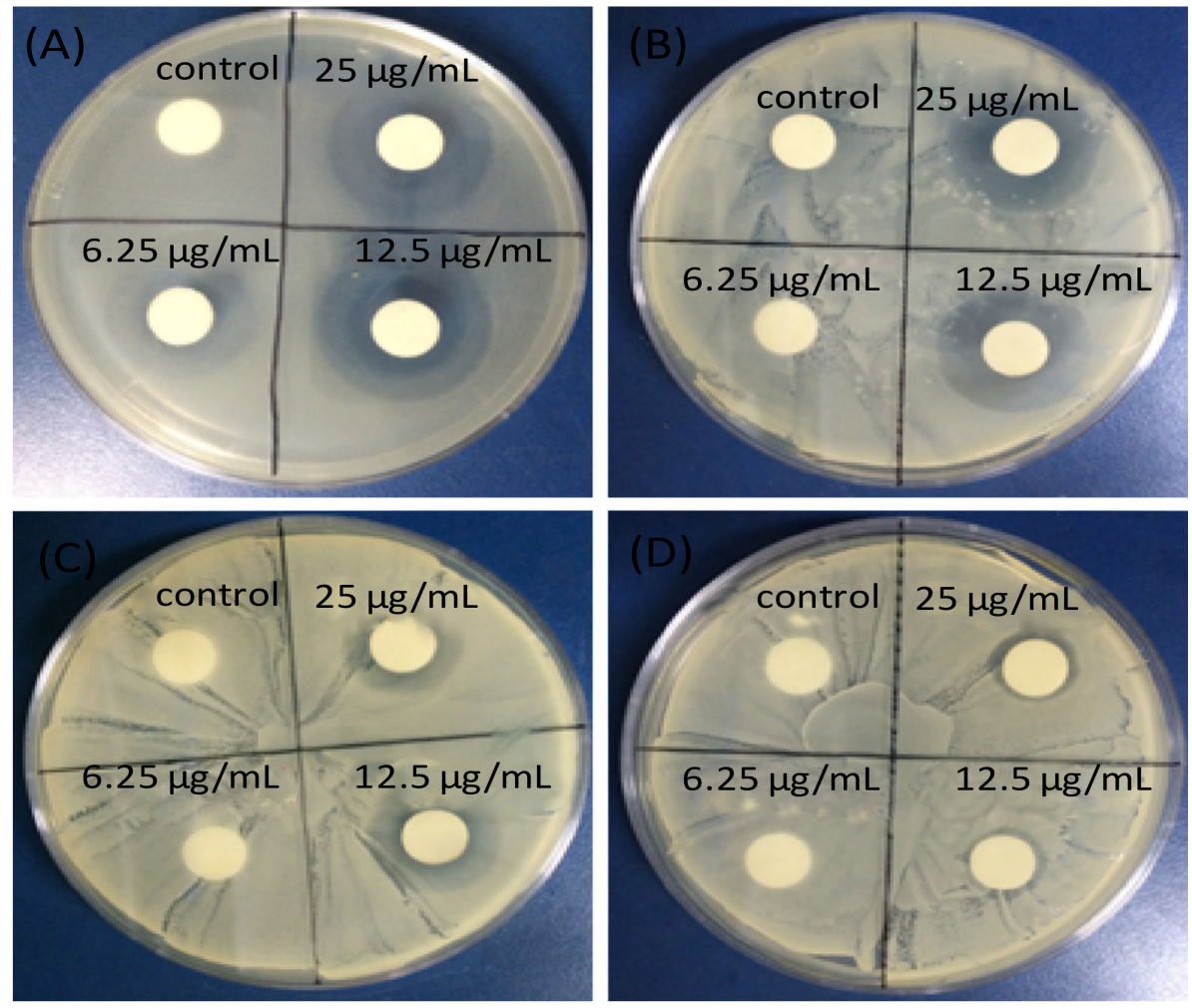

Figure 9. Inhibitory zones of ZnO-GO nanocomposite against (A) Escherichia coli; (B) Salmonella typhimurium; (C) Bacillus subtilis; (D) Enterococcus faecalis. Adapted from Ref. [91], with permission from Dove Medical Press, 2015.

This enhanced behaviour is ascribed to cell membrane disruption due to the release of the $\mathrm{Zn}^{2+}$ ions and the ROS production. Thus, $\mathrm{Zn}^{2+}$ can link to the negatively charged bacterial membrane, causing the protein on the membrane to solidify, thus inhibiting the bacterial proliferation. Besides, electrons can be quickly transferred between the $\mathrm{ZnO}$ nanoparticles and the $\mathrm{GO}$, and subsequently absorb surface oxygen to form ROS, resulting in the formation of lipid peroxide, consequently damaging the bacterial membrane.

The nanocomposite synthesis method also influences the antibacterial activity. Those prepared via electrophoretic deposition (EPD) showed better properties than those manufactured via drop-casting [84]. Thus, the EPD method led to effective penetration of the negatively charged $\mathrm{GO}$ sheets into $\mathrm{ZnO}$ nanowires to form a spider net-like structure, whereas the drop-casting technique caused only the surface coverage of the GO sheets onto the nanowires. The $\mathrm{ZnO}$ nanowires alone could just inactivate $58 \%$ of $E$. coli, while both drop-casting and EPD-prepared GO/ZnO nanocomposites displayed significant antibacterial activity; in particular, the EPD one caused $99.5 \%$ photoinactivation under visible light irradiation for $1 \mathrm{~h}$ at a concentration of $500 \mu \mathrm{g} / \mathrm{mL}$, Table 1.

\subsection{Multicomponent Nanocomposites}

Several graphene-based multicomponent composites have been prepared by incorporating different nanoparticles with graphene or its derivatives, in order to attain improved antibacterial activity due to synergistic effects. For instance, $\mathrm{GO}-\mathrm{Ag}-\mathrm{TiO}_{2}$ nanocomposite coatings were synthesized using a hydrothermal process for the control of the food-borne pathogen Campylobacter jejuni. The nanocomposites efficiently inhibited the aggregation and growth of $C$. jejuni as well as biofilm formation [92]. Different nanocomposites incorporating iron oxide nanoparticles have also been developed [93-97], Table 1. Magnetic GO- $\mathrm{MnFe}_{2} \mathrm{O}_{4}$ hybrids at a concentration of $100 \mu \mathrm{g} / \mathrm{mL}$ led to about $82 \%$ inhibition on E. coli after only $2 \mathrm{~h}$ of contact [95]. Hybrids with polyethylenimine wrapped 
Ag nanoparticles and $\mathrm{Fe}_{2} \mathrm{O}_{3}$ caused $100 \%$ inhibition of E. coli at a concentration of only $0.1 \mu \mathrm{g} / \mathrm{mL}$ [93]. A multicomposite of $\mathrm{GO}, \mathrm{CoFe}_{2} \mathrm{O}_{4}$, and $\mathrm{Ag}$ nanoparticles was also manufactured to disinfect water contaminated with E. coli and S. aureus, leading to almost complete inhibition at $12 \mu \mathrm{g} / \mathrm{mL}$ [96]. GO decorated with $\mathrm{Ag}, \mathrm{TiO}_{2}$, and $\mathrm{ZnO}$ nanostructures has been prepared via ultrasonication and casting, and the antibacterial activity of the nanocomposite was tested against Gram-positive S. aureus and B. anthracoides and Gram-negative E. coli and P. multocida [98]. Figure 10 shows SEM images of GO, $\mathrm{Ag}$, GO-Ag, $\mathrm{GO}-\mathrm{TiO}_{2}-\mathrm{ZnO}$, and $\mathrm{GO}-\mathrm{Ag}-\mathrm{TiO}_{2}-\mathrm{ZnO}$ nanocomposites.

Table 1. Antibacterial properties of nanocomposites with graphene-based materials and inorganic NPs (S: spherical; QS: quasi-spherical; E: ellipsoidal; C: cubic; T: triangular; NW: nanowire; ST: star).

\begin{tabular}{|c|c|c|c|c|c|}
\hline $\begin{array}{l}\text { Graphene } \\
\text { Material }\end{array}$ & $\begin{array}{c}\text { NP shape/ } \\
\text { size }(\Phi, \text { nm) }\end{array}$ & Bacteria Model & $\begin{array}{c}\text { Concentration } \\
(\mu \mathrm{g} / \mathrm{mL})\end{array}$ & $\begin{array}{c}\text { Inhibition } \\
(\%)\end{array}$ & Ref. \\
\hline AgNPs-GO & S/93 & S. enteritidis & 200 & 61 & [51] \\
\hline AgNPs-GO & $\mathrm{S} / 80$ & E. coli & 200 & 89 & [52] \\
\hline AgNPs-GO & $\mathrm{S} / 80$ & S. epidermidis & 200 & 76 & [52] \\
\hline AgNPs-GO & $\mathrm{S} / 80$ & S. aureus & 200 & 81 & [52] \\
\hline AgNPs-GO & $\mathrm{S} / 80$ & C. albicans & 200 & 78 & [52] \\
\hline AgNPs-GO & S, QS & E. coli/S. aureus & 100 & 100 & [53] \\
\hline AgNPs-GO & $\mathrm{QS} / 40$ & E. coli & 6.4 & 100 & [55] \\
\hline AgNPs-GO & QS/60 & E. coli/S. aureus & 10 & 100 & [56] \\
\hline AgNPs-GO & $\mathrm{E} / 98$ & E. coli/S. aureus & 45 & 100 & [57] \\
\hline AgNPs-GO & $\mathrm{S} / 40$ & E. coli & 2.5 & 80 & [58] \\
\hline AgNPs-GO & $\mathrm{S} / 40$ & S. aureus & 2.5 & 78 & [58] \\
\hline AgNPs-GO & $\mathrm{S} / 3.1$ & S. aureus & 64 & 100 & [62] \\
\hline AgNPs-GO & $\mathrm{S} / 3.1$ & C. albicans & 64 & 100 & [62] \\
\hline AgNPs-GO & $\mathrm{S} / 3.1$ & E. coli/P. aeruginosa & 128 & 100 & [62] \\
\hline AgNPs-rGO & QS/57 & E. coli & 40 & 100 & [54] \\
\hline AgNPs-rGO & $\widehat{S} / 12$ & E. coli & 20 & 100 & [59] \\
\hline Au-rGO & $\mathrm{T}, \mathrm{S} / 50$ & S. aureus/B. subtilis & 250 & 94 & [67] \\
\hline Au-rGO & $\mathrm{T}, \mathrm{S} / 50$ & E. coli/P. aeruginosa & 250 & 50 & [67] \\
\hline Au-rGO & $\mathrm{T}, \mathrm{S}$ & E. coli & 10 & 99 & [68] \\
\hline $\mathrm{Cu}_{2} \mathrm{ONPs}-\mathrm{rGO}$ & $\mathrm{C} / 30$ & E. coli & 40 & 70 & [71] \\
\hline $\mathrm{Cu}_{2} \mathrm{ONPs-rGO}$ & $\mathrm{C} / 30$ & S. aureus & 40 & 65 & [71] \\
\hline CuONPs-GO & $\mathrm{E} / 80$ & E. coli & 3.0 & 90 & [72] \\
\hline CuONPs-GO & $\mathrm{E} / 80$ & S. typhimurium & 3.0 & 99 & [72] \\
\hline $\mathrm{TiO}_{2}-\mathrm{GO}$ & $\mathrm{S} / 30$ & E. coli & 180 & 100 & [77] \\
\hline $\mathrm{ZnO}-\mathrm{GO}$ & NW/75 & E. coli & 500 & 100 & [84] \\
\hline $\mathrm{ZnO}-\mathrm{GO}$ & $\mathrm{ST} / 150$ & E. coli/P. aeruginosa & 6.5 & 100 & [86] \\
\hline $\mathrm{ZnO}-\mathrm{GO}$ & ST/150 & S. aureus & 11.5 & 100 & [86] \\
\hline $\mathrm{ZnO}-\mathrm{GO}$ & ST/150 & B. subtilis & 15.0 & 100 & [86] \\
\hline ZnO-G & $\mathrm{S} / 20$ & E. coli & 3.0 & 100 & [89] \\
\hline $\mathrm{Ag}-\mathrm{Fe}_{2} \mathrm{O}_{3}-\mathrm{rGO}$ & QS & E. coli & 0.1 & 100 & [93] \\
\hline $\mathrm{Fe}_{2} \mathrm{O}_{3-} \mathrm{GO}$ & $\mathrm{S} / 225$ & E. coli & 100 & 97 & [94] \\
\hline $\mathrm{MnFe}_{2} \mathrm{O}_{4}-\mathrm{GO}$ & $\mathrm{S} / 170$ & E. coli & 100 & 82 & [95] \\
\hline $\mathrm{Ag}-\mathrm{CoFe}{ }_{2} \mathrm{O}_{4}-\mathrm{rGO}$ & QS/75 & E. coli/S. aureus & 12 & 98 & [96] \\
\hline $\mathrm{Fe}_{3} \mathrm{O}_{4}-\mathrm{GO}$ & $\mathrm{S} / 66$ & E. coli & 300 & 91 & [97] \\
\hline
\end{tabular}



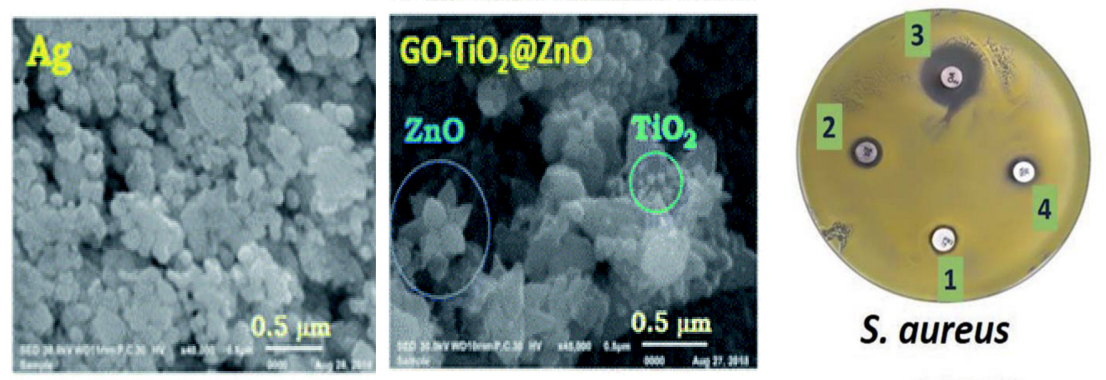

S. aureus
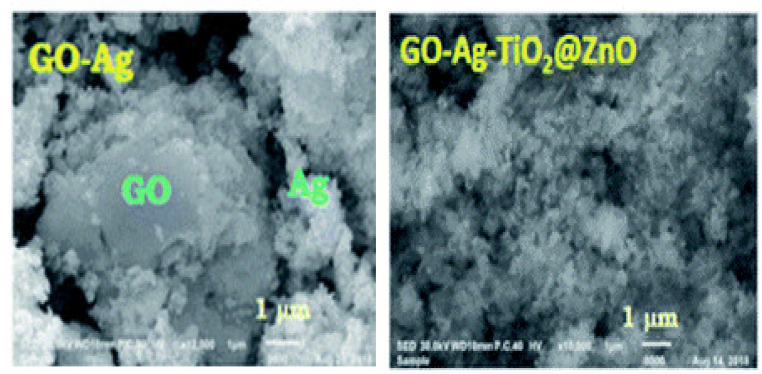

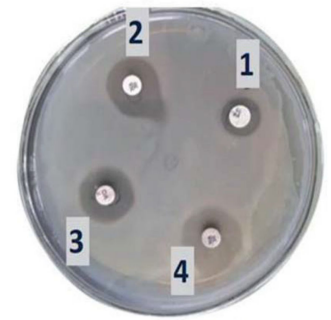

P. multocida

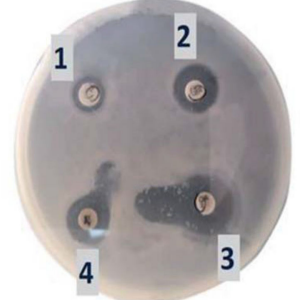

B. anthracoide

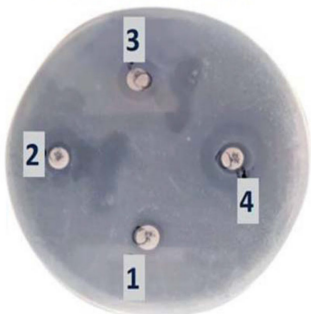

E. coli

Figure 10. Left: SEM images of Ag, GO-Ag, GO-TiO2@ZnO, and GO-Ag-TiO2@ZnO nanocomposite. Right: Inhibitory zones of GO-Ag-TiO2@ZnO nanocomposite against S. aureus, B. anthracoides and Gram-negative E. coli and P. multocida. Adapted from Ref. [98], with permission from the Royal Society of Chemistry, 2019.

As can be observed, the GO nanosheet was densely packed by the metal oxides, representative of a good combination between the carbon nanomaterial and the inorganic NPs. Thus, the GO nanosheets seem to act as bridges for the metal oxide NPs. Ag NPs have a spherical morphology and are located on the GO surface. The $\mathrm{ZnO}$ nanoflower appears over the GO surface, while the spherical $\mathrm{TiO}_{2}$ is deposited onto the $\mathrm{ZnO}$ nanoflower. The Ag NPs alone had the lowest inhibitory effect on all tested bacteria. The $\mathrm{GO}-\mathrm{TiO}_{2}-\mathrm{ZnO}$ nanocomposite showed highly suppressing microbial growth against both Gram-positive and Gram-negative bacteria, while the four-component nanocomposite was found to be the most effective against Gram-negative bacteria (Figure 10). The improved activity of the hybrid was ascribed to the synergistic effect of the different components: direct damage of the cellular membrane by the Ag nanoparticles, $\mathrm{ROS}$ generation by the $\mathrm{TiO}_{2}$ and $\mathrm{ZnO}$, contact between the $\mathrm{GO}$ sharp edges and the bacteria, and the accumulation of the nanoparticles in the cytoplasm.

$\mathrm{Ag} / \mathrm{ZnO} / \mathrm{rGO}$ nanocomposites with different weight ratios were synthesized via rapid microwave irradiation [99]. Depending on the composition, the hybrids were more effective against Gram positive or Gram negative bacteria, and the optimal performance was found at $7 \mathrm{wt} \% \mathrm{Ag}$ and $15 \mathrm{wt} \% \mathrm{ZnO}$. Further, multifunctional nanocomposites of GO incorporating both $\mathrm{Ag}$ and $\mathrm{Fe}_{2} \mathrm{O}_{3}$ nanoparticles were prepared and characterized [100]. The MIC values against E. coli and S. aureus were 0.025 and $0.05 \mathrm{mg} / \mathrm{mL}$, respectively These composites display both antibacterial and magnetic properties, and can be harvested with a magnet.

On the other hand, hydroxyapatite (HA) $\left(\mathrm{Ca}_{10}\left(\mathrm{PO}_{4}\right)_{6}(\mathrm{OH})_{2}\right)$, has excellent biocompatibility, osteoconductivity, is non-toxic, and is widely used for biomedical applications [101]. rGO/HA/Ag multicomponent nanocomposites have been prepared using the hydrothermal method [102] and characterized via different spectroscopic techniques. They showed improved antibacterial activity against $B$. cereus, S. aureus, E. coli and K. pneumonia than the pure components.

Overall, the comparison of the data in Table 1 reveals that the optimum bactericide efficacy at the lowest concentration $(0.1 \mu \mathrm{g} / \mathrm{mL})$ is attained for the hybrid nanocomposite comprising $\mathrm{Ag}^{+} \mathrm{NPs}$, rGO and $\mathrm{Fe}_{3} \mathrm{O}_{4}$, with an antibacterial performance superior to those ever reported for photothermal materials, arising from the synergistic effect of the three components [93]. 


\section{Concluding Remarks and Outlook}

Selected examples about the progress on graphene-based antibacterial nanocomposites incorporating inorganic nanoparticles have been provided. It has been demonstrated that the nanoparticles present higher antibacterial activity compared with their bulk counterparts due to their higher surface-to-volume ratio, resulting in improved contact with microorganisms. The antimicrobial properties of the nanocomposites have been usually tested versus E. Coli and S. Aureus as model microorganism. In this regard, ongoing research should focus on other bacteria such as S. Epidermidis, S. enteritidis, S. typhimurium P. aeruginosa, E. faecalis, B. subtilis, etc., in order to provide a better perspective on the general antibacterial ability of graphene-based materials. This would account for the increasing antibiotic resistance among various bacteria and their association as a severe hazard to worldwide public health.

Generally, these nanomaterials cause stronger damage towards E. coli compared to S. Aureus, which could be related to the structural and chemical compositional differences of the cell membranes. Gram-positive bacteria possess one cytoplasmic membrane and a dense wall comprising multilayers of peptidoglycan, whereas Gram-negative have a multipart cell wall structure, with a peptidoglycan layer between the outer membrane and the cytoplasmic membrane.

Although the disparity in nanomaterial concentrations, syntheses processes, antibacterial measurement methods, and so forth make the comparison of the antimicrobial effectiveness difficult, it seems that nanocomposites loaded with Ag nanoparticles are the most effective, followed by those incorporating photocatalytic nanoparticles like $\mathrm{TiO}_{2}$ and $\mathrm{ZnO}$. Furthermore, various multicomponent materials have been developed by combining different NPs or metal oxide NPs, which lead to higher antibacterial activity than the individual components and at much lower concentration due to a synergetic effect.

Another issue related to these nanomaterials is the large number of parameters influencing the antibacterial properties, including size, shape, orientation, defects as well as surface functional groups. Well-dispersed nanomaterials show stronger antibacterial activity than the aggregated ones. Further, composites with small-sized NPs are more effective since they have larger surface area in contact with the bacteria. On the other hand, triangular-shaped NPs display better activity towards Gram-positive and Gram-negative bacteria than spherical ones, since their sharp edges can penetrate cell membranes more easily.

The antibacterial activity of these nanocomposites seems to be a combination of different mechanisms, including release of inorganic NP ions, penetration through the cell membrane, ROS generation, DNA, protein, mitochondrion, and lipid damage as well as bacteria cell disruption. The last mechanism appears to be the key mechanism against Gram-negative bacteria, while the DNA, protein, mitochondrion, and lipid damage, resulting in inhibition of cell division could account for the lysis of Gram-positive ones.

Nonetheless, although the antimicrobial mechanism of graphene-based nanomaterials has been the aim of a number of recent investigations, the field is still in its infancy, and much controversial data has been reported; hence, a deeper and comprehensive knowledge of the molecular mechanisms involved is required. The main challenge is obtaining reliable information on the interaction between bacteria and graphene-based nanomaterials, as well as the effect of different parameters including basal planes, lateral size, oxygen content, etc. Another challenge is to analyze the toxicity associated with them. Despite numerous studies on this topic, there are inconsistencies in the results and lack of universal acceptance criteria for the toxicity of graphene-based materials, which urgently have to be solved prior to their use in practical applications.

Notwithstanding the challenges, it is expected that the progress made by scientists in developing graphene-based nanocomposites as antibacterial agents will be productive in the future. We should all collaborate with novel ideas to address the associated challenges.

Funding: This research received no external funding. 
Acknowledgments: Ana M. Díez-Pascual acknowledges the Ministerio de Economía y Competitividad (MINECO) for the "Ramón y Cajal" Research Fellowship, co-financed by the EU.

Conflicts of Interest: The authors declare no conflict of interest.

\section{References}

1. Diez-Pascual, A.M. Antibacterial activity of nanomaterials. Nanomaterials 2018, 8, 359. [CrossRef]

2. Wong, K.K.Y.; Liu, X. Silver nanoparticles-the real-silver bullet in clinical medicine? Med. Chem. Comm. 2010, 1, 125-131. [CrossRef]

3. Chang, H.; Wu, H. Graphene-based nanomaterials: Synthesis, properties, and optical and optoelectronic applications. Adv. Funct. Mater. 2013, 23, 1984-1997. [CrossRef]

4. Weiss, N.O.; Zhou, H.; Liao, L.; Liu, Y.; Jiang, S.; Huang, Y.; Duan, X. Graphene: An emerging electronic material. Adv. Mater. 2012, 24, 5782-5825. [CrossRef] [PubMed]

5. Lee, C.; Wei, X.; Kysar, J.W.; Hone, J. Measurement of the elastic properties and intrinsic strength of monolayer graphene. Science 2008, 321, 385-388. [CrossRef] [PubMed]

6. Diez-Pascual, A.M.; Gomez-Fatou, M.A.; Ania, F.; Flores, A. Nanoindentation in polymer nanocomposites. Prog. Mater. Sci. 2015, 67, 1-94. [CrossRef]

7. Kuilla, T.; Bhadra, S.; Yao, D.; Kim, N.H.; Bose, S.; Lee, J.H. Recent advances in graphene based polymer composites. Prog. Polym. Sci. 2010, 35, 1350-1375. [CrossRef]

8. Zheng, Q.; Kim, J.K. Synthesis, structure and properties of graphene and graphene oxide. In Graphene for transparent conductors. synthesis, properties and applications; Springer: New York, NY, USA, 2015; pp. $29-94$. ISBN 978-1493927685.

9. Dreyer, D.R.; Park, S.; Bielawski, C.W.; Ruoff, R.S. The chemistry of graphene oxide. Chem. Soc. Rev. 2010, 39, 228-240. [CrossRef]

10. Smith, A.T.; LaChance, A.M.; Zeng, S.; Liu, B.; Sun, L. Synthesis, properties and applications of graphene oxide/reduced graphene oxide and their nanocomposites. Nano Mate. Sci. 2019, 1,31-47. [CrossRef]

11. Suk, J.W.; Piner, R.D.; An, J.; Ruoff, R.S. Mechanical properties of monolayer graphene oxide. ACS Nano 2010, 4, 6557-6564. [CrossRef]

12. Diez-Pascual, A.M.; Diez-Vicente, A.L. Poly(propylene fumarate)/polyethylene glycol-modified graphene oxide nanocomposites for tissue engineering. ACS Appl. Mater. Interfaces 2016, 8, 17902-17914. [CrossRef]

13. Chen, J.; Yao, B.; Li, C.; Shi, G. An improved Hummers method for eco-friendly synthesis of graphene oxide. Carbon 2013, 64, 225-229. [CrossRef]

14. Renteria, J.D.; Ramirez, S.; Malekpour, H.; Alonso, B.; Centeno, A.; Zurutuza, A.; Cocemasov, A.I.; Nika, D.L.; Balandin, A.A. Strongly Anisotropic Thermal Conductivity of Free-Standing Reduced Graphene Oxide Films Annealed at High Temperature. Adv. Funct. Mat. 2015, 25, 4664-4692. [CrossRef]

15. Pei, S.; Chen, H.-M. The reduction of graphene oxide. Carbon 2012, 50, 3210-3228. [CrossRef]

16. Cote, L.J.; Cruz-Silva, R.; Huang, J. Flash reduction and patterning of graphene oxide and its polymer composite. J. Am. Chem. Soc. 2009, 131, 11027-11032. [CrossRef] [PubMed]

17. Zhang, Y.; Guo, L.; Wei, S.; He, Y.; Xia, H.; Chen, Q.; Sun, H.-B.; Xiao, F.-S. Direct imprinting of microcircuits on graphene oxides film by femtosecond laser reduction. Nano Today 2010, 5, 15-20. [CrossRef]

18. Díez-Pascual, A.M.; Luceño Sánchez, J.A.; Peña Capilla, R.; García Díaz, P. Recent advances in graphene/polymer nanocomposites for applications in polymer solar cells. Polymers 2018, 10, 217. [CrossRef]

19. Fernandez-Merino, J.; Guardia, L.; Paredes, J.I.; Villar-Rodil, S.; Solis-Fernandez, P.; Martinez-Alonso, A.; Tascon, J.M.D. Vitamin C is an ideal substitute for hydrazine in the reduction of graphene oxide suspensions. J. Phys. Chem. C 2010, 114, 6426-6432. [CrossRef]

20. Zhang, Z.; Chen, H.; Xing, C.; Guo, M.; Xu, F.; Wang, X.; Gruber, H.J.; Zhang, B.; Tang, J. Sodium citrate: A universal reducing agent for reduction/decoration of graphene oxide with au nanoparticles. Nano Res. 2011, 4, 599. [CrossRef]

21. Kamińska, I.; Das, M.R.; Niedziółka-Jönsson, J.; Woisel, P.; Lyskawa, J.; Opałło, M.; Boukherroub, R.; Szunerits, $\mathrm{S}$. Reduction and functionalization of graphene oxide sheets using biomimetic dopamine derivatives in one step. ACS Appl. Mater. Interfaces 2012, 4, 1016-1020. [CrossRef] 
22. Diez-Pascual, A.M.; Sainz-Urruela, C.; Vallés, C.; Vera-López, S.; San Andrés, M.P. Tailorable synthesis of highly oxidized graphene oxides via an environmentally-friendly electrochemical process. Nanomaterials 2020, 10, 239. [CrossRef] [PubMed]

23. Erol, O.; Uyan, I.; Hatip, M.; Yilmaz, C. Recent advances in bioactive 1D and 2D carbon nanomaterials for biomedical applications. Nanomed. Nanotechnol. 2018, 14, 2433-2454. [CrossRef]

24. Liao, C.; Li, Y.; Tjong, S.C. Graphene nanomaterials: Synthesis, biocompatibility, and cytotoxicity. Int. J. Mol. Sci. 2018, 19, 3564. [CrossRef]

25. Syama, S.; Mohanan, P.V. Safety and biocompatibility of graphene: A new generation nanomaterial for biomedical application. Int. J. Biol. Macromol. 2016, 86, 546-555. [CrossRef] [PubMed]

26. Ou, L.; Song, B.; Liang, H.; Liu, J.; Feng, X.; Deng, B.; Sun, T.; Shao, L. Toxicity of graphene-family nanoparticles: A general review of the origins and mechanisms. Part. Fibre Toxicol. 2016, 13, 57. [CrossRef] [PubMed]

27. Wu, Y.; Wang, F.; Wang, S.; Ma, J.; Xu, M.; Gao, M.; Liu, R.; Chen, W.; Liu, S. Reduction of graphene oxide alters its cyto-compatibility towards primary and immortalized macrophages. Nanoscale 2018, 10, 14637-14650. [CrossRef] [PubMed]

28. Majidi, H.J.; Babaei, A.; Bafrani, Z.A.; Shahrampour, D.; Zabihi, E.; Jafari, S.M. Investigating the best strategy to diminish the toxicity and enhance the antibacterial activity of graphene oxide by chitosan addition. Carbohydr. Polym. 2019, 225, 115-220. [CrossRef]

29. Tang, X.-Z.; Mu, C.; Zhu, W.; Yan, X.; Hu, X.; Yang, J. Flexible polyurethane composites prepared by incorporation of polyethylenimine-modified slightly reduced graphene oxide. Carbon 2016, 98, 432-440. [CrossRef]

30. Some, S.; Ho, S.-M.; Dua, P.; Hwang, E.; Shin, Y.H.; Yoo, H.; Kang, J.-S.; Lee, D.-K.; Lee, H. Dual functions of highly potent graphene derivative-poly-l-lysine composites to inhibit bacteria and support human cells. ACS Nano 2012, 6, 7151-7161. [CrossRef]

31. Yang, S.; Brüller, S.; Wu, Z.S.; Liu, Z.; Parvez, K.; Dong, R.; Richard, F.; Samorì, P.; Feng, X.; Müllen, K. Organic radical-assisted electrochemical exfoliation for the scalable production of high-quality graphene. J. Am. Chem. Soc. 2015, 137, 13927-13932. [CrossRef]

32. Romero-Vargas Castrillón, S.; Perreault, F.; De Faria, A.F.; Elimelech, M. Interaction of graphene oxide with bacterial cell membranes: Insights from force spectroscopy. Environ. Sci. Technol. Lett. 2015, 2, 112-117. [CrossRef]

33. Perreault, F.; De Faria, A.F.; Nejati, S.; Elimelech, M. Antimicrobial properties of graphene oxide nanosheets: Why size matters. ACS Nano 2015, 9, 7226-7236. [CrossRef]

34. Yi, X.; Gao, H. Cell interaction with graphene microsheets: Near-orthogonal cutting versus parallel attachment. Nanoscale 2015, 7, 5457-5467. [CrossRef] [PubMed]

35. Dallavalle, M.; Calvaresi, M.; Bottini, A.; Melle-France, M.; Zerbetto, F. Graphene can wreak havoc with cell membranes. ACS Appl. Mater. Interfaces 2015, 7, 4406-4414. [CrossRef] [PubMed]

36. Romero, M.P.; Marangoni, V.S.; Gonçalves de Faria, C.; Leite, I.S.; Castro e Silva, C.C.; Maroneze, C.M.; Pereira-da-Silva, M.A.; Bagnato, V.S.; Inada, N.M. Graphene oxide mediated broad-spectrum antibacterial based on bimodal action of photodynamic and photothermal effects. Front. Microbiol. 2020, 10, 2995. [CrossRef]

37. Liu, S.; Zeng, T.H.; Hofmann, M.; Burcombe, E.; Wei, J.; Jiang, R.; Kong, J.; Chen, Y. Antibacterial activity of graphite, graphite oxide, graphene oxide, and reduced graphene oxide: Membrane and oxidative stress. ACS Nano 2011, 5, 6971-6980. [CrossRef] [PubMed]

38. Akhavan, O.; Ghaderi, E. Toxicity of graphene and graphene oxide nanowalls against bacteria. ACS Nano 2010, 4, 5731-5736. [CrossRef]

39. Luan, B.; Huynh, T.; Zhao, L.; Zhou, R. Potential toxicity of graphene to cell functions via disrupting protein-protein interactions. ACS Nano 2015, 9, 663-669. [CrossRef]

40. Liu, S.; Hu, M.; Zeng, T.H.; Wu, R.; Jiang, R.; Wei, J.; Wang, L.; Kong, J.; Chen, Y. Lateral dimension-dependent antibacterial activity of graphene oxide sheets. Langmuir 2012, 28, 12364-12372. [CrossRef]

41. Kurantowicz, N.; Sawosz, E.; Jaworski, S.; Kutwin, M.; Strojny, B.; Wierzbicki, M.; Szeliga, J.; Hotowy, A.; Lipinska, L.; Kozinski, R.; et al. Interaction of graphene family materials with Listeria monocytogenes and Salmonella enterica. Nanoscale Res Lett 2015, 10, 23. [CrossRef] 
42. Li, J.; Wang, G.; Zhu, H.; Zhang, M.; Zheng, X.; Di, Z.; Liu, X.; Wang, X. Antibacterial activity of large-area monolayer graphene film manipulated by charge transfer. Sci. Rep. 2014, 4, 4359. [CrossRef] [PubMed]

43. Chen, J.; Peng, H.; Wang, X.; Shao, F.; Yuan, Z.; Han, H. Graphene oxide exhibits broad-spectrum antimicrobial activity against bacterial phytopathogens and fungal conidia by intertwining and membrane perturbation. Nanoscale 2014, 6, 1879-1889. [CrossRef]

44. Gurunathan, S.; Han, J.W.; Dayem, A.A.; Eppakayala, V.; Kim, J.-H. Oxidative stress-mediated antibacterial activity of graphene oxide and reduced graphene oxide in Pseudomonas aeruginosa. Int. J. Nanomed. 2012, 7, 5901-5914. [CrossRef] [PubMed]

45. Mangadlao, J.D.; Santos, C.M.; Felipe, M.J.L.; de Leon, A.C.C.; Rodrigues, D.F.; Advincula, R.C. On the antibacterial mechanism of graphene oxide (GO) Langmuir-Blodgett films. Chem. Commun. 2015, 51, 2886-2889. [CrossRef] [PubMed]

46. Hui, L.; Piao, J.G.; Auletta, J.; Hu, K.; Zhu, Y.; Meyer, T.; Liu, H.-Y.; Yang, L. Availability of the basal planes of graphene oxide determines whether it is antibacterial. ACS Appl. Mater. Interfaces 2014, 6, 13183-13190. [CrossRef] [PubMed]

47. Rizzello, L.; Pompa, P.P. Nanosilver-based antibacterial drugs and devices: Mechanisms, methodological drawbacks, and guidelines. Chem. Soc. Rev. 2014, 43, 1501-1518. [CrossRef] [PubMed]

48. Panáček, A.; Kvitek, L.; Prucek, R.; Kolář, M.; Večeřová, R.; Pizúrová, N.; Sharma, V.K.; Nevěčá, T.j.; Zbořil, R. Silver colloid nanoparticles: Synthesis, characterization, and their antibacterial activity. J. Phys. Chem. B 2006, 110, 16248-16253. [CrossRef]

49. Tong, Y.; Bohm, S.; Song, M. Graphene based materials and their composites as coatings. Austin. J. Nanomed. Nanotechnol. 2014, 1, 1003.

50. Fan, Z.; Liu, B.; Wang, J.; Zhang, S.; Lin, Q.; Gong, P.; Ma, L.; Yang, S. A novel wound dressing based on Ag/graphene polymer hydrogel: Effectively kill bacteria and accelerate wound healing. Adv. Funct. Mater. 2014, 24, 3933-3943. [CrossRef]

51. Wierzbicki, M.; Jaworski, S.; Sawosz, E.; Jung, A.; Gielerak, G.; Jaremek, H.; Łojkowski, W.; Woźniak, B.; Stobiński, L.; Małolepszy, A.; et al. Graphene oxide in a composite with silver nanoparticles reduces the fibroblast and endothelial cell cytotoxicity of an antibacterial nanoplatform. Nanoscale Res. Lett. 2019, 14, 320. [CrossRef]

52. Jaworski, S.; Wierzbicki, M.; Sawosz, E.; Jung, A.; Gielerak, G.; Biernat, J.; Jaremek, H.; Łojkowski, W.; Woźniak, B.; Wojnarowicz, J.; et al. Graphene oxide-based nanocomposites decorated with silver nanoparticles as an antibacterial agent. Nanoscale Res. Lett. 2018, 13, 116. [CrossRef] [PubMed]

53. Nguyen, V.H.; Kim, B.-K.; Jo, Y.-L.; Shim, J.-J. Preparation and antibacterial activity of silver nanoparticles-decorated graphene composites. J. Supercrit. Fluids 2012, 72, 28-35. [CrossRef]

54. Moghayedi, M.; Goharshadi, E.K.; Ghazvini, K.; Ahmadzadeh, H.; Ranjbaran, L.; Masoudi, R.; Ludwig, R. Kinetics and mechanism of antibacterial activity and cytotoxicity of Ag-RGO nanocomposite. Coll. Surf. B Biointerfaces 2017, 159, 366-374. [CrossRef]

55. Zhu, Z.; Su, M.; Ma, L.; Ma, L.; Liu, D.; Wang, Z. Preparation of graphene oxide-silver nanoparticle nanohybrids with highly antibacterial capability. Talanta 2013, 117, 449-455. [CrossRef] [PubMed]

56. Ganguly, S.; Das, P.; Bose, M.; Das, T.K.; Mondal, S.; Das, A.K.; Das, N.C. Sonochemical green reduction to prepare Ag nanoparticles decorated graphene sheets for catalytic performance and antibacterial application. Ultrasonics Sonochem. 2017, 39, 577-588. [CrossRef] [PubMed]

57. Bao, Q.; Zhang, D.; Qi, P. Synthesis and characterization of silver nanoparticle and graphene oxide nanosheet composites as a bactericidal agent for water disinfection. J. Colloid Interface Sci. 2011, 360, 463-470. [CrossRef]

58. Tang, J.; Chen, Q.; Xu, L.Q.; Zhang, S.; Feng, L.; Cheng, L.; Xu, H.; Liu, Z.; Peng, R. Graphene oxide-silver nanocomposite as a highly effective antibacterial agent with species-specific mechanisms. ACS Appl. Mater. Interfaces 2013, 5, 3867-3874. [CrossRef]

59. Zhou, Y.; Yang, J.; He, T.; Shi, H.; Cheng, X.; Lu, Y. Highly stable and dispersive silver nanoparticle-graphene composites by a simple and low-energy-consuming approach and their antimicrobial activity. Small 2013, 9, 3445-3454. [CrossRef]

60. Song, B.; Zhang, C.; Zeng, G.; Gong, J.; Chang, Y.; Jiang, Y. Antibacterial properties and mechanism of graphene oxide-silver nanocomposites as bactericidal agents for water disinfection. Arch. Biochem. Biophys. 2016, 604, 167-176. [CrossRef] 
61. Chen, X.; Huang, X.; Zheng, C.; Liu, Y.L.; Xu, T.; Liu, J. Preparation of different sized nano-silver loaded on functionalized graphene oxide with highly effective antibacterial properties. J. Mater. Chem. B 2015, 3, 7020. [CrossRef]

62. Cobos, M.; de-la-Pinta, I.; Quindós, G.; Fernández, M.J.; Fernández, M.A. Graphene oxide-silver nanoparticle nanohybrids: Synthesis, characterization, and antimicrobial properties. Nanomaterials 2020, 10, 376. [CrossRef] [PubMed]

63. Akter, M.; Sikder, M.T.; Rahman, M.; Ullah, A.K.; Hossain, K.F.; Banik, S.; Hosokawa, T.; Saito, T.; Kurasaki, M. A systematic review on silver nanoparticles-induced cytotoxicity: Physicochemical properties and perspectives. J. Adv. Res. 2018, 9, 1-16. [CrossRef] [PubMed]

64. Bindhu, M.R.; Umadevi, M. Antibacterial activities of green synthesized gold nanoparticles. Mater Lett 2014, 120, 122-125. [CrossRef]

65. Smitha, S.L.; Gopchandran, K.G. Surface enhanced Raman scattering, antibacterial and antifungal active triangular gold nanoparticles. Spectrochim. Acta A Mol. Biomol. Spectrosc. 2013, 102, 114-119. [CrossRef]

66. Rai, A.; Prabhune, A.; Perry, C.C. Antibiotic mediated synthesis of gold nanoparticles with potent antimicrobial activity and their application in antimicrobial coatings. J. Mater. Chem. 2010, 20, 6789-6798. [CrossRef]

67. Hussain, N.; Gogoi, A.; Sarma, R.K.; Sharma, P.; Barras, A.; Boukherroub, R.; Saikia, R.; Sengupta, P.; Das, M.R. Reduced graphene oxide nanosheets decorated with Au nanoparticles as an effective bactericide: Investigation of biocompatibility and leakage of sugars and proteins. ChemPlusChem 2014, 79, 1774-1784. [CrossRef]

68. Turcheniuk, T.; Hage, C.-H.; Spadavecchia, J.; Serrano, A.Y.; Larroulet, I.; Pesquera, A.; Zurutuza, A.; Pisfil, M.G.; Heliot, L.; Bouckaert, J.; et al. Plasmonic photothermal destruction of uropathogenic E. coli with reduced graphene oxide and core/shell nanocomposites of gold nanorods/reduced graphene oxide. J. Mater. Chem. B 2015, 3, 375-386. [CrossRef]

69. Ouyang, Y.; Cai, X.; Shi, Q.; Liu, L.; Wan, D.; Tan, S.; Ouyang, Y. Poly-L-lysine-modified reduced graphene oxide stabilizes the copper nanoparticles with higher water-solubility and long-term additively antibacterial activity. Coll. Surf. B Biointerfaces 2013, 107, 107-114. [CrossRef]

70. Wang, M.Y.; Huang, J.R.; Tong, Z.W.; Li, W.H.; Chen, J. Reduced graphene oxide cuprous oxide composite via facial deposition for photocatalytic dyedegradation. J. Alloy. Compd. 2013, 568, 26-35. [CrossRef]

71. Yang, Z.; Hao, X.; Chen, S.; Ma, Z.; Wang, W.; Wang, C.; Yue, L.; Sun, H.; Shao, Q.; Murugadoss, V. Long-term antibacterial stable reduced graphene oxide nanocomposites loaded with cuprous oxide nanoparticles. J. Colloid Interface Sci. 2019, 533, 13-23. [CrossRef]

72. Rajapaksha, P.; Cheeseman, S.; Hombsch, S.; Murdoch, B.J.; Gangadoo, S.; Blanch, E.W.; Truong, Y.; Cozzolino, D.; McConville, C.F.; Crawford, R.J.; et al. Antibacterial properties of graphene oxide-copper oxide nanoparticle nanocomposites. ACS Appl. Bio Mater. 2019, 2, 5687-5696. [CrossRef]

73. Diez-Pascual, A.M.; Diez-Vicente, A.L. Nano-TiO2 Reinforced PEEK/PEI blends as biomaterials for load-bearing implant applications. ACS Appl. Mater. Interfaces 2015, 7, 5561-5573. [CrossRef] [PubMed]

74. Diez-Pascual, A.M.; Diez-Vicente, A.L. Development of linseed oil-TiO2 green nanocomposites as antimicrobial coatings. J. Mater. Chem. B 2015, 3, 4458-4471. [CrossRef] [PubMed]

75. Diez-Pascual, A.M.; Diez-Vicente, A.L. Effect of TiO2 nanoparticles on the performance of polyphenylsulfone biomaterial for orthopaedic implants. J. Mater. Chem. B 2014, 2, 7502-7514. [CrossRef] [PubMed]

76. Liu, J.; Liu, L.; Bai, H.; Wang, Y.; Sun, D.D. Gram-scale production of graphene oxide-TiO2 nanorod composites: Towards high-activity photocatalytic materials. Appl. Catal. B Environ. 2011, 106, 76-82. [CrossRef]

77. Chang, Y.-N.; Ou, X.-M.; Zeng, G.-M.; Gong, J.-L.; Deng, C.-H.; Jiang, Y.; Liang, J.; Yuan, G.-Q.; Liu, H.-Y.; $\mathrm{He}, \mathrm{X}$. Synthesis of magnetic graphene oxide-TiO2 and their antibacterial properties under solar irradiation. Appl. Surf. Sci. 2015, 343, 1-10. [CrossRef]

78. Stan, M.S.; Nica, I.C.; Popa, M.; Chifiriuc, M.C.; Iordache, O.; Dumitrescu, I.; Diamandescu, L.; Dinischiotu, A. Reduced graphene oxide/TiO2 nanocomposites coating of cotton fabrics with antibacterial and self-cleaning properties. J. Ind. Text. 2019, 49, 277-293. [CrossRef]

79. Guo, H.; Jiang, N.; Wang, H.; Shang, K.; Lu, N.; Li, J.; Wu, Y. Enhanced catalytic performance of graphene-TiO2 nanocomposites for synergetic degradation of fluoroquinolone antibiotic in pulsed discharge plasma system. Appl. Catal. B Environ. 2019, 248, 552-566. [CrossRef] 
80. Sher shah, M.S.A.; Park, A.R.; Zhang, K.; Park, J.H.; Yoo, P.J. Green synthesis of biphasic TiO2-reduced graphene oxide nanocomposites with highly enhanced photocatalytic activity. ACS Appl. Mater. Interfaces 2012, 4, 3893-3901. [CrossRef]

81. Diez-Pascual, A.M.; Diez-Vicente, A.L. High-Performance aminated poly(phenylene sulphide)/ZnO nanocomposites for medical applications. ACS Appl. Mater. Interfaces 2014, 6, 10132-10145. [CrossRef]

82. Diez-Pascual, A.M.; Diez-Vicente, A.L. Epoxidized soybean oil/ZnO biocomposites for soft tissue applications: Preparation and characterization. ACS Appl. Mater. Interfaces 2014, 6, 17277-17288. [CrossRef]

83. Diez-Pascual, A.M.; Diez-Vicente, A.L. Development of nanocomposites reinforced with carboxylated poly(ether ether ketone)-grafted to zinc oxide with superior antibacterial properties. ACS Appl. Mater. Interfaces 2014, 6, 3729-3741. [CrossRef]

84. Nourmohammadi, A.; Rahighi, R.; Akhavan, O.; Moshfegh, A. Graphene oxide sheets involved in vertically aligned zinc oxide nanowires for visible light photoinactivation of bacteria. J. Alloys Comp. 2014, 612, 380-385. [CrossRef]

85. Trinh, L.T.; Quynh, L.A.B.; Hieu, N.H. Synthesis of zinc oxide/graphene oxide nanocomposite material for antibacterial application. Int. J. Nanotechnol. 2018, 15, 108-117. [CrossRef]

86. Archana, S.; Kumar, K.Y.; Jayanna, B.; Olivera, S.; Anand, A.; Prashanth, M.; Muralidhara, H. Versatile Graphene oxide decorated by star shaped Zinc oxide nanocomposites with superior adsorption capacity and antimicrobial activity. J. Sci. Adv. Mater. Devices 2018, 3, 167-174. [CrossRef]

87. Wang, Y.-W.; Cao, A.; Jiang, Y.; Zhang, X.; Liu, J.-H.; Liu, Y.; Wang, H. Superior antibacterial activity of zinc oxide/graphene oxide composites originating from high zinc concentration localized around bacteria. ACS Appl. Mater. Interfaces 2014, 6, 2791-2798. [CrossRef] [PubMed]

88. Wu, D.; An, T.; Li, G.; Wang, W.; Cai, Y.; Yip, H.Y.; Zhao, H.; Wong, P.K. Mechanistic study of the visible-light-driven photocatalytic inactivation of bacteria by graphene oxide-zinc oxide composite. Appl. Surf. Sci. 2015, 358, 137-145. [CrossRef]

89. Kavitha, T.; Gopalan, A.I.; Lee, K.-P.; Park, S.-Y. Glucose sensing, photocatalytic and antibacterial properties of graphene-ZnO nanoparticle hybrids. Carbon 2012, 50, 2994-3000. [CrossRef]

90. Liu, J.; Rojas-Andrade, M.D.; Chata, G.; Peng, Y.; Roseman, G.; Lu, J.-E.; Millhauser, G.L.; Saltikov, C.; Chen, S. Photo-enhanced antibacterial activity of $\mathrm{ZnO} /$ graphene quantum dot nanocomposites. Nanoscale 2018, 10, 158-166. [CrossRef] [PubMed]

91. Zhong, L.; Yun, K. Graphene oxide-modified ZnO particles: Synthesis, characterization, and antibacterial properties. Int. J. Nanomed. 2015, 10, 79-92.

92. Noreen, Z.; Khalid, N.; Abbasi, R.; Javed, S.; Ahmad, I.; Bokhari, H. Visible light sensitive Ag/TiO2/graphene composite as a potential coating material for control of Campylobacter jejuni. Mater. Sci. Eng. C 2019, 98, 125-133. [CrossRef]

93. Wang, N.; Hu, B.; Chen, M.-L.; Wang, J.-H. Polyethylenimine mediated silver nanoparticle-decorated magnetic graphene as a promising photothermal antibacterial agent. Nanotechnology 2015, 26, 195703. [CrossRef] [PubMed]

94. Santhosh, C.; Kollu, P.; Doshi, S.; Sharma, M.; Bahadur, D.; Vanchinathan, M.T.; Saravanan, P.; Kim, B.-S.; Grace, A.N. Adsorption, photodegradation and antibacterial study of graphene-Fe3O4 nanocomposite for multipurpose water purification application. RSC Adv. 2014, 4, 28300-28308. [CrossRef]

95. Chella, S.; Kollu, P.; Komarala, E.V.P.; Doshi, S.; Saranya, M.; Felix, S.; Ramachandran, R.; Saravanan, P.; Koneru, V.L.; Venugopal, V. Solvothermal synthesis of MnFe2O4-graphene composite-Investigation of its adsorption and antimicrobial properties. Appl. Surf. Sci. 2015, 327, 27-36. [CrossRef]

96. Ma, S.; Zhan, S.; Jia, Y.; Zhou, Q. Highly efficient antibacterial and Pb (II) removal effects of Ag-CoFe2O4-GO nanocomposite. ACS Appl. Mater. Interfaces 2015, 7, 10576-10586. [CrossRef] [PubMed]

97. Deng, C.-H.; Gong, J.-L.; Zeng, G.-M.; Niu, C.-G.; Niu, Q.-Y.; Zhang, W.; Liu, H.-Y. Inactivation performance and mechanism of Escherichia coli in aqueous system exposed to iron oxide loaded graphene nanocomposites. J. Hazardous Mater. 2014, 276, 66-76. [CrossRef]

98. El-Shafai, N.; El-Khouly, M.E.; El-Kemary, M.; Ramadan, M.; Eldesoukeye, I.; Masouda, M. Graphene oxide decorated with zinc oxide nanoflower, silver and titanium dioxide nanoparticles: Fabrication, characterization, DNA interaction, and antibacterial activity. RSC Adv. 2019, 9, 3704. [CrossRef] 
99. Hsueh, Y.-H.; Hsieh, C.-T.; Chiu, S.-T.; Tsai, P.-H.; Liu, C.-Y.; Ke, W.-J. Antibacterial Property of Composites of Reduced Graphene Oxide with Nano-Silver and Zinc Oxide Nanoparticles Synthesized Using a Microwave-Assisted Approach. Int. J. Mol. Sci. 2019, 20, 5394. [CrossRef]

100. Moosavi, R.; Ramanathan, S.; Lee, Y.Y.; Ling, K.C.S.; Afkhami, A.; Archunan, G.; Padmanabhan, P.; Gulyás, B.; Kakran, M.; Selvan, S.T. Synthesis of antibacterial and magnetic nanocomposites by decorating graphene oxide surface with metal nanoparticles. RSC Adv. 2015, 5, 76442-76450. [CrossRef]

101. Diez-Pascual, A.M.; Diez-Vicente, A.L. Multifunctional poly(glycolic acid-co-propylene fumarate) electrospun fibers reinforced with graphene oxide and hydroxyapatite nanorods. J. Mater. Chem. B 2017, 5, 4084-4096. [CrossRef]

102. Beiranvand, M.; Farhadi, S.; Mohammadi, A. Graphene Oxide/Hydroxyapatite/Silver (rGO/HAP/Ag) nanocomposite: Synthesis, characterization, catalytic and antibacterial activity. Int. J. Nano Dimens. 2019, 10, 180-194.

(C) 2020 by the author. Licensee MDPI, Basel, Switzerland. This article is an open access article distributed under the terms and conditions of the Creative Commons Attribution (CC BY) license (http://creativecommons.org/licenses/by/4.0/). 